\title{
The Past, Present and Future of Auer Deference: Mead, Form and Function in Judicial Review of Agency Interpretations of Regulations
}

\author{
Michael P. Healy*
}

\section{INTRODUCTION}

The law of judicial review of agency legal interpretations has undergone an important reshaping as a consequence of the Supreme Court decision in United States v. Mead Corp. ${ }^{1}$ That decision and the important follow-on decision in National Cable \& Telecommunications Ass' $n$ v. Brand X Internet Services ${ }^{2}$ have changed the understanding of the Court's landmark 1984 decision in Chevron, U.S.A., Inc. v. Natural Resources Defense Council, Inc. ${ }^{3}$ Chevron defined a new era of judicial deference to an agency's interpretation of an ambiguous statute, ${ }^{4}$ but the Chevron era has itself been transformed. ${ }^{5}$

These legal developments had seemed to have little consequential impact on a related legal doctrine that is also at the center of the relationship between courts and agencies. Regulations have come to provide the applicable source of public law in an increasing number of cases and now occupy a place in administrative law that is comparable to the place of statutes. ${ }^{6}$ Regulations share an important characteristic with

* Wendell H. Ford Professor of Law, University of Kentucky College of Law. J.D., 1984, University of Pennsylvania; B.A., 1978 Williams College. The author thanks Kent Barnett and Collin Schueler for reviewing an earlier draft of this article. The author is responsible for any errors.

1. 533 U.S. 218 (2001). The significance of Mead and its impact on agency interpretations of statutes are addressed in Michael P. Healy, Reconciling Chevron, Mead, and the Review of Agency Discretion: Source of Law and the Standards of Judicial Review, 19 GEO. MASON L. REV. 1 (2011).

2. 545 U.S. 967 (2005). See generally Healy, supra note 1, at 18-25 (discussing Mead and Brand $X)$.

3. 467 U.S. 837 (1984). See generally Healy, supra note 1, at 15-18 (discussing the Chevron decision).

4. See Healy, supra note 1 , at $15-18$.

5. See id. at 2.

6. See John F. Manning, Constitutional Structure and Judicial Deference to Agency Interpretations of Agency Rules, 96 COLUM. L. REV. 612, 614-15 (1996) (“[R]egulations frequently play a more direct role than statutes in defining the public's legal rights and obligations." (footnote omitted)); Kevin M. Stack, Interpreting Regulations, 111 MicH. L. REv. 355, 356-57 (2012) ("The 
statutes: both are often ambiguous. ${ }^{7}$ The standard that applies when a court reviews an agency's interpretation of an ambiguous regulation had been initially defined by Bowles v. Seminole Rock \& Sand Co. ${ }^{8}-\mathrm{a}$ decision that predated the Administrative Procedure Act (APA). ${ }^{9}$ This early decision had been accepted wholeheartedly by the Court after Chevron, most notably in Auer v. Robbins. ${ }^{10}$ The resulting black-letter law - that courts will defer to any reasonable agency interpretation of its own regulations - had seemed to have exactly the same effect as Chevron deference. ${ }^{11}$ Because of the significance of regulations in administrative law, this rule of deference has played a critical role in defining the relationship between courts and agencies. ${ }^{12}$

This tidy rule of deference has now come to be far less tidy and secure as a result of a quintet of recent Supreme Court decisions. These decisions-Gonzales v. Oregon, ${ }^{13}$ Coeur Alaska, Inc. v. Southeast Alaska

ascendance of statutory interpretation occurred, however, as regulations issued by administrative agencies eclipsed statutes as sources of law. With the rise of regulations, lawyers and judges now routinely confront questions of interpretation on this next frontier - that is, the interpretation of regulations themselves." (footnote omitted)); id. at 365 ("In the 1960s and 1970s, agencies increasingly turned to rulemaking to implement their statutory powers. Agency reliance on rulemaking has persisted. Today, the majority of agencies issue their most significant policies through notice-and-comment rulemaking." (footnotes omitted)); see also id. at 357 ("While all agree that regulations are primary sources of law, strikingly little attention has been devoted to the method of their interpretation.").

7. See Stack, supra note 6, at 365-66 ("With the rise of rulemaking, it is hard to deny a naive expectation ... that agency regulations would resolve legal ambiguities, not create them. To be sure, many regulations clarify legal obligations. But regulations are not unique among legal sources for their lack of ambiguity or the obviousness of their interpretation. At times, regulations replicate statutory ambiguities; in other instances, they create their own. Changed and unforeseen circumstances also unsettle the interpretation of regulations that had appeared to be clear." (footnotes omitted)).

8. 325 U.S. 410 (1945).

9. The APA was enacted in 1946. Administrative Procedure Act, Pub. L. No. 79-404, 60 Stat. 237 (1946) (codified as amended in 5 U.S.C.).

10. 519 U.S. 452 (1997). See infra notes 78-129 and accompanying text (discussing Seminole Rock deference after Chevron).

11. See Decker v. Nw. Envtl. Def. Ctr., 133 S. Ct. 1326, 1339-40 (2013) (Scalia, J., concurring in part and dissenting in part) ("In practice, Auer deference is Chevron deference applied to regulations rather than statutes. The agency's interpretation will be accepted if, though not the fairest reading of the regulation, it is a plausible reading - within the scope of the ambiguity that the regulation contains." (citation omitted)).

12. See id. at 1339 (Roberts, C.J., concurring) ("The issue is a basic one going to the heart of administrative law. Questions of Seminole Rock and Auer deference arise as a matter of course on a regular basis."); Manning, supra note 6, at 615 ("Because agency rules that comply with specified procedural formalities bind with the force of statutes, Seminole Rock has a significant impact on the public's legal rights and obligations." (footnote omitted)).

13. 546 U.S. 243 (2006). 
Conservation Council, ${ }^{14}$ Talk America, Inc. v. Michigan Bell Telephone Co., ${ }^{15}$ Christopher v. SmithKline Beecham Corp., ${ }^{16}$ and Decker v. Northwest Environmental Defense Center ${ }^{17}$-have had a cumulative effect on Auer deference that resembles the impact that Mead has had on Chevron deference. These cases reveal a Court that has come to view Auer deference as either less deferential than or equivalent to Chevron deference, and subject to a test for the (uncertain) standard's applicability. ${ }^{18}$ The Court is, however, reshaping this law of deference with little apparent understanding of the impact of its decisions. Moreover, the Court has provided little rationale for its changes in the law.

This article will assess this developing, but under-analyzed, ${ }^{19}$ area of administrative law. The first part describes the past of the long-accepted rule of deference to an agency's interpretation of its own regulations. ${ }^{20}$ The second part discusses the Court's recent changes in its approach to the traditional rule of deference, highlighting the degree to which the Court is now less willing to defer to an agency's interpretation of its own regulations. $^{21}$

The final part of the article discusses the future of deference in this context and seeks to accommodate the functional and formal reasons for a rule of deference. ${ }^{22}$ In short, this part presents a theoretical rationale for a new non-deferential standard of review.

\footnotetext{
14. 557 U.S. 261 (2009).

15. 131 S. Ct. 2254 (2011).

16. 132 S. Ct. 2156 (2012).

17. 133 S. Ct. 1326 (2013).

18. See infra notes $236-47$ and accompanying text.

19. See Matthew C. Stephenson \& Miri Pogoriler, Seminole Rock's Domain, 79 GEO. WASH. L. REV. 1449, 1503-04 (2011) ("Federal judges and administrative law scholars continue to wrestle with the appropriate scope of Chevron's domain. Especially in the wake of Mead, this issue has generated more controversy, and more sophisticated scholarly commentary, than perhaps any other single doctrinal problem in administrative law. It is therefore somewhat surprising that no comparable discussion has taken place about the appropriate domain of Seminole Rock, Chevron's vitally important but sometimes neglected counterpart."); $i d$. at 1504 ("The comparative neglect of questions regarding Seminole Rock's domain risks incoherence, unpredictability, and erosion of important safeguards against administrative arbitrariness."); Manning, supra note 6, at 614 ("Seminole Rock deference . . . has long been one of the least worried-about principles of administrative law.").

20. See infra Part II.

21. See infra Part III.

22. See infra Part IV.
} 


\section{THE UNDERTHEORIZED PAST OF THE RULE OF DEFERENCE TO AN AGENCY'S INTERPRETATION OF ITS OWN REGULATIONS}

\section{A. The Simple Point of Beginning: Bowles v. Seminole Rock \& Sand Co. ${ }^{23}$}

Seminole Rock involved the administration of price controls during World War II. ${ }^{24}$ The Emergency Price Control Act of 1942 had delegated to the Administrator of the Office of Price Administration the authority to promulgate regulations to implement price controls. ${ }^{25}$ The issue was whether the seller of crushed stone could sell its product for a maximum of $\$ 1.50$ per ton or $\$ 0.60$ per ton based on its sale price during the month of March 1942. ${ }^{26}$ The higher price was the amount charged for crushed stone ordered, but not delivered, during that month, while the lower price was paid for crushed stone that was actually delivered during the month. ${ }^{27}$

The court of appeals concluded that the agency had committed a legal error when it decided that $\$ 0.60$ was the maximum permissible price. ${ }^{28}$ The court stated its view that, when a court reviews an agency's interpretation of a statute or its regulations, the court employs the same review standard: "In order to be binding upon and enforceable by the courts, administrative interpretations either of the law or regulations having the force and effect of law must be in harmony with and tend to effectuate the cardinal purposes of the law, and may not be unreasonable." 29 The court then concluded that the agency's interpretation was both "unreasonable and [] antagonistic to the letter and spirit of the Act." 30

The Supreme Court reversed the court of appeals and provided, without any analytic explanation, ${ }^{31}$ a famous and long-effective standard

\footnotetext{
23. 325 U.S. 410 (1945).

24. Id. at 411 .

25. See id. at 412.

26. See Bowles v. Seminole Rock \& Sand Co., 145 F.2d 482, 484 (5th Cir. 1944), rev'd, 325 U.S. 410 (1945).

27. $I d$.

28. See id.

29. Id. (footnote omitted).

30. Id. at 485 .

31. See Decker v. Nw. Envtl. Def. Ctr., 133 S. Ct. 1326, 1340 (2013) (Scalia, J., concurring in part and dissenting in part) ("Our cases have not put forward a persuasive justification for Auer deference. The first case to apply it, Seminole Rock, offered no justification whatever-just the ipse dixit that 'the administrative interpretation . . . becomes of controlling weight unless it is plainly
} 
for reviewing agency interpretations of its regulations:

Since [the problem in this case] involves an interpretation of an administrative regulation a court must necessarily look to the administrative construction of the regulation if the meaning of the words used is in doubt. The intention of Congress or the principles of the Constitution in some situations may be relevant in the first instance in choosing between various constructions. But the ultimate criterion is the administrative interpretation, which becomes of controlling weight unless it is plainly erroneous or inconsistent with the regulation. ${ }^{32}$

The strong rule of deference described by the Court is, however, undercut by the analysis that follows the Court's statement of the rule. The Court begins its analysis by quoting the definition that the regulation provided for the key legal term:

'Highest price charged during March, 1942' means

(i) The highest price which the seller charged to a purchaser of the same class for delivery of the article or material during March, 1942; or

(ii) If the seller made no such delivery during March, 1942, such seller's highest offering price to a purchaser of the same class for delivery of the article or material during that month; or

(iii) If the seller made no such delivery and had no such offering price to a purchaser of the same class during March, 1942, the highest price charged by the seller during March, 1942, to a purchaser of a different class, adjusted to reflect the seller's customary differential between the two classes of purchasers[.] $]^{33}$

The Court then presented what it viewed as the "evident" meaning of this definition: "The facts of each case must first be tested by rule (i); only if that rule is inapplicable may rule (ii) be utilized; and only if both rules (i) and (ii) are inapplicable is rule (iii) controlling." 34

erroneous or inconsistent with the regulation."' (citation omitted)); Manning, supra note 6, at 619 ("[T]he Court in Seminole Rock did not offer any detailed rationale for binding deference."); Stephenson \& Pogoriler, supra note 19, at 1454 ("The Seminole Rock Court offered no explanation whatsoever - nor even a citation to any other authority - for its conclusion that a reviewing court must uphold an administrative interpretation of a regulation that is not clearly erroneous or inconsistent with the regulation." (footnote omitted)).

32. Bowles v. Seminole Rock \& Sand Co., 325 U.S. 410, 413-14 (1945) (emphasis added).

33. Id. at 414 (quoting $\S 1499.163(\mathrm{a})(2)$ ).

34. Id. at 415 . 
Based on this "evident" meaning of the definition, the Court concluded that there was a "clear[]" rather than ambiguous meaning of the price regulation that followed from the Court's own close reading of the text:

As we read the regulation, however, rule [i] clearly applies to the facts of this case, making 60 cents per ton the ceiling price for respondent's crushed stone. The regulation recognizes the fact that more than one meaning may be attached to the phrase 'highest price charged during March, 1942.' The phrase might be construed to mean only the actual charges or sales made during March, regardless of the delivery dates. Or it might refer only to the charges made for actual delivery in March. Whatever may be the variety of meanings, however, rule (i) adopts the highest price which the seller 'charged for delivery' of an article during March, 1942. The essential element bringing the rule into operation is thus the fact of delivery during March. If delivery occurs during that period the highest price charged for such delivery becomes the ceiling price. Nothing is said concerning the time when the charge or sale giving rise to the delivery occurs. One may make a sale or charge in October relative to an article which is actually delivered in March and still be said to have "charged for delivery during March.' We can only conclude, therefore, that for purposes of rule (i) the highest price charged for an article delivered during March, 1942, is the seller's ceiling price regardless of the time when the sale or charge was made. ${ }^{35}$

The Court's close textual analysis of the regulatory definition continued when it stated:

This conclusion is further borne out by the fact that rule [ii] becomes applicable only where 'the seller made no such delivery during March, 1942,' as contemplated by rule (i). The absence of a delivery, rather than the absence of both a charge and a delivery during March, is necessary to make rule (i) ineffective, thereby indicating that the factor of delivery is the essence of rule (i).

The Court's textual analysis of the regulation ended with its conclusion:

It is apparent, moreover, that the delivery must be an actual instead of a constructive one. Section 1499.20(d) of General Maximum Price Regulation, incorporated by reference into Maximum Price Regulation No. 188 by Section 1499.151, defines the word 'delivered' as meaning 'received by the purchaser or by any carrier for shipment to the

35. Id. at $415-16$ (emphasis added) (footnote omitted).

36. Id. at 416 . 
purchaser' during March, 1942. Thus an article is not 'delivered' to a purchaser during March because of the existence of an executory contract under which no shipments are actually made to him during that month. In short, the Administrator in rule (i) was concerned with what actually was delivered, not with what might have been delivered. ${ }^{3}$

Only after this extensive analysis of the regulatory text does the Court turn its attention to the agency's own interpretation of the regulation. The Court quoted two examples of the agency's construction of the regulation ${ }^{38}$ and referred as well to the fact that "the Administrator has stated that this position has uniformly been taken by the Office of Price Administration in the countless explanations and interpretations given to inquirers affected by this type of maximum price determination." 39

Given the nature of its analysis, it is not surprising that the Court explained its holding in the case as follows:

Our reading of the language of Section 1499.163(a)(2) of Maximum Price Regulation No. 188 and the consistent administrative interpretation of the phrase 'highest price charged during March, 1942' thus compel the conclusion that respondent's highest price charged during March for crushed stone was 60 cents per ton, since that was the highest price charged for stone actually delivered during that month. The two courts below erred in their interpretation of this regulation and the judgment below must accordingly be reversed. ${ }^{40}$

In short, although Seminole Rock has become well known to administrative lawyers for establishing the rule that a court must defer to an agency's reasonable interpretation of its own regulations, ${ }^{41}$ that rule of deference did not determine the result in the case. The Court itself construed the regulation and found that it provided a clear answer to the legal question. The Court used the agency's interpretations only as a make weight, bolstering its own reading of the regulations. Applying modern terminology to the Supreme Court's decision in Seminole Rock,

37. Id. at $416-17$.

38. Id. at 417.

39. Id. at $417-18$.

40. Id. at 418 (footnote omitted).

41. See, e.g., Stack, supra note 6, at 368 (describing "the well-established doctrine, attributed to Bowles v. Seminole Rock \& Sand Co. and Auer v. Robbins, that an agency's construction of its own regulation is controlling unless plainly erroneous or inconsistent with the regulation" (footnotes omitted) (quotation marks omitted)). 
one might say that the Court said Chevron step-two deference applied ${ }^{42}$ to its review of the agency interpretation. The Court then concluded that the meaning of the regulation was clear - analogous to a Chevron stepone decision. ${ }^{43}$ The agency's interpretation was actually insignificant to the Court's interpretation of the regulation's text, viewed as unambiguous by the Court. The agency would have had to amend its regulations before it could have interpreted them as Seminole Rock had advocated.

Decisions by the Supreme Court in the years after Seminole Rock, and prior to the 1984 Chevron decision, applied the deferential standard that the Court had identified when reviewing agency interpretations of regulations. The Court's analysis in two of these cases, decided after the enactment in 1946 of the APA, ${ }^{44}$ indicated that that statute had no effect on the Court's understanding of the proper review standard. In Power Reactor Development Co. v. International Union of Electrical, Radio and Machine Workers, ${ }^{45}$ the Court considered the question: "whether the [Atomic Energy] Commission, in issuing a permit for the construction of a facility which will utilize nuclear materials ... must make the same definitive finding of safety of operation as it admittedly will have to make before it licenses actual operation of the facility." 46 The Court concluded that the statute was ambiguous regarding this question. ${ }^{47}$ The Court accordingly turned to the regulations to decide the legal question. ${ }^{48}$

The Court's analytic method is then similar to its method in Seminole Rock. ${ }^{49}$ The Court first closely read the text of the regulation and concluded that its meaning was clear:

We think the great weight of the argument supports the position ... that

42. See Chevron, U.S.A., Inc. v. Natural Res. Def. Council, Inc., 467 U.S. 837, 843 (1984) (" $[\mathrm{I} \mathrm{f}$ the statute is silent or ambiguous with respect to the specific issue, the question for the court is whether the agency's answer is based on a permissible construction of the statute.").

43. See id. at 842-43 ("First, always, is the question whether Congress has directly spoken to the precise question at issue. If the intent of Congress is clear, that is the end of the matter; for the court, as well as the agency, must give effect to the unambiguously expressed intent of Congress."). See generally Healy, supra note 1, at 15-18.

44. Administrative Procedure Act, Pub. L. No. 79-404, 60 Stat. 237 (1946) (codified as amended in 5 U.S.C.).

45. 367 U.S. 396 (1961).

46. Id. at 398 .

47. Id. at 406 ("There is nothing on the face of either $\S 182$ or $\S 185$ which tells us what safety findings must be made before this preliminary step [of issuing a construction permit] is taken. We know, however, from $\$ 104$, subd. $b$ that some such finding must be made.").

48. See id. at 406-08.

49. See supra notes $41-43$ and accompanying text. 
Reg. 50.35 permits the Commission to defer a definitive safety finding until operation is actually licensed. The words of the regulation themselves certainly lean strongly in that direction. The first finding is to be made, by definition, on the basis of incomplete information, and concerns only the 'general type' of reactor proposed. The second finding is phrased unequivocally in terms of 'reasonable assurance,' while the first speaks more tentatively of 'information sufficient to provide reasonable assurance.' The Commission, furthermore, had good reason to make this distinction. For nuclear reactors are fastdeveloping and fast-changing. What is up to date now may not, probably will not, be as acceptable tomorrow. Problems which seem insuperable now may be solved tomorrow, perhaps in the very process of construction itself. ${ }^{50}$

Having presented its understanding of the regulatory text, the Court added the gloss of deference, stating the rule of deference as uniformly applicable to an agency interpretation of its regulation and its statute: "We see no reason why we should not accord to the Commission's interpretation of its own regulation and governing statute that respect which is customarily given to a practical administrative construction of a disputed provision." 51 The Court then opined that according deference to the Commission was "particularly" appropriate in this case. Its reasoning in this regard was notable. First, the Court believed that "the administrative practice at stake involves a contemporaneous construction of a statute by the men charged with the responsibility of setting its machinery in motion; of making the parts work efficiently and smoothly while they are yet untried and new." ${ }^{.2}$ This language reinforces that the Court saw deference to agency interpretations of regulations as equivalent to agency interpretations of statutes. The reasoning also reflects the traditional judicial view of the expertise of agencies and the strong functional rationale for deference. ${ }^{53}$ This reasoning, of course, makes no distinction based on the source of the law being interpreted: the statute is Congress-made law, while the regulation is agency-made law. This latter source of law distinction is critical to the theory of deference

50. Power Reactor Dev., 367 U.S. at 407-08.

51. Id. at 408. This statement of the rule of deference is very similar to the statement of the rule of deference by the court of appeals in Seminole Rock. See supra text accompanying note 29.

52. Id. (citation omitted) (quotation marks omitted).

53. See Stephenson \& Pogoriler, supra note 19, at 1459 ("The main pragmatic arguments in favor of deferring to an agency's construction of its own regulation are clear and familiar. First and foremost, such deference may promote competent and efficient administration of complex government programs. Agencies, according to a widely held and plausible view, often possess technical expertise that courts lack - both with respect to the subject matter and how different parts of a complicated regulatory scheme fit together."). 
in modern administrative law. ${ }^{54}$

The Court's final argument on why deference was "particularly" appropriate in this case was that the statute had not been amended after the congressional committee had been informed of the agency's interpretation. The Court commented that the agency's construction:

has time and again been brought to the attention of the Joint Committee of Congress on Atomic Energy, which under $\S 202$ of the Act, 42 U.S.C. $§ 2252$, has a special duty during each session of Congress 'to conduct hearings in either open or executive session for the purpose of receiving information concerning the development, growth, and state of the atomic energy industry,' and to oversee the operations of the AEC. No change in this procedure has ever been suggested by the Committee, although it has on occasion been critical of other aspects of the PRDC proceedings not before us. It may often be shaky business to attribute significance to the inaction of Congress, but under these circumstances, and considering especially the peculiar responsibility and place of the Joint Committee on Atomic Energy in the statutory scheme, we think it fair to read this history as a de facto acquiescence in and ratification of the Commission's licensing procedure by Congress. This same procedure has been used in each of the nine instances in which the Commission has granted a provisional construction permit for a developmental nuclear power reactor, and we hold that it was properly used in this case. ${ }^{55}$

This rationale reinforces the Court's view that the same rule of deference applies because the Court saw no legal difference between an agency's interpretation of a statute and of its regulations. The Court's rationale here, however, is anachronistic in two respects. First, the Court's expressed willingness to rely on a congressional committee's acquiescence is in tension with the separation of powers principles defined by INS v. Chadha. ${ }^{56}$ A congressional committee should not have the power to shape an agency's understanding of a previously enacted statute. Second, the Court has again demeaned the significance of the source of law to our understanding of deference. If Congress has delegated lawmaking power to an agency, the agency has the power to exercise that authority independently of Congress. Congress has authority only to make, but not to execute, the laws, and it makes law only by enacting statutes. ${ }^{57}$

54. See Healy, supra note 1, at 33, 39-40.

55. Power Reactor Dev., 367 U.S. at 408-09 (citations omitted).

56. 462 U.S. 919 (1983).

57. See id. at 955 ("Congress must abide by its delegation of authority [to an agency] until that 
Several years after the decision in Power Reactor Development, the Court decided one of the best known pre-Chevron cases describing the rule of deference to agency legal decisions. In Udall v. Tallman, ${ }^{58}$ Chief Justice Warren presented the Court's unanimous opinion in a case that necessitated the application of an executive and departmental order to the question of whether certain lands were available for mineral leasing. ${ }^{59}$ The case did not involve the interpretation of a statute. The Court restated the deferential rule defined by Seminole Rock: "The Secretary's interpretation may not be the only one permitted by the language of the orders, but it is quite clearly a reasonable interpretation; courts must therefore respect it. McLaren v. Fleischer, 256 U.S. 477, 481; Bowles v. Seminole Rock Co., 325 U.S. 410, 413-414." ${ }^{, 60}$ By relying on McLaren $v$. Fleischer, in addition to Seminole Rock, the Court indicated its understanding that deference to interpretations of orders or regulations was identical to deference to interpretations of statutes. McLaren, decided in 1921, involved only the interpretation of a statute; there was neither a regulation nor an order to interpret. ${ }^{61}$

The Court emphasized this understanding of deference when, later in the Udall v. Tallman decision, Chief Justice Warren stated that deference to an agency interpretation of a regulation is even more appropriate than deference to an agency's interpretation of a statute. ${ }^{62}$ The Court did add another rationale for deference: notice and the reliance resulting from the application of a well-settled interpretation. ${ }^{63}$ The Court's decisions in

delegation is legislatively altered or revoked." (footnote omitted)).

58. 380 U.S. 1 (1965).

59. Id. at 3-4.

60. Id. at 4 .

61. See McLaren v. Fleischer, 256 U.S. 477, 481 (1921) ("If not the only reasonable construction of the act, it is at least an admissible one. It therefore comes within the rule that the practical construction given to an act of Congress, fairly susceptible of different constructions, by those charged with the duty of executing it is entitled to great respect and, if acted upon for a number of years will not be disturbed except for cogent reasons.").

62. 380 U.S. at $16-17$ ("When faced with a problem of statutory construction, this Court shows great deference to the interpretation given the statute by the officers or agency charged with its administration. ... When the construction of an administrative regulation rather than a statute is in issue, deference is even more clearly in order." (emphasis added) (citations omitted) (quotation marks omitted)).

63. See id. at 17-18 ("The Secretary's interpretation had, long prior to respondents' applications, been a matter of public record and discussion. The agreement worked out with the House Committee on Merchant Marine and Fisheries in $1956 \ldots$ though probably constituting no 'legislative ratification' in any formal sense, serve[s] to demonstrate the notoriety of the Secretary's construction, and thereby defeat any possible claim of detrimental reliance upon another interpretation. Finally, almost the entire area covered by the orders in issue has been developed, at very great expense, in reliance upon the Secretary's interpretation." (footnote omitted)). 
Udall v. Tallman and Power Reactor Development did not rely on the APA in the discussion of the rule of deference or the application of that rule.

In sum, the rule of judicial deference to an agency's interpretation of its own regulations was well settled prior to the Chevron decision. The settled nature of this rule did not, however, reflect a careful analysis of the reasons for such deference. ${ }^{64}$ The Court did not embrace any formal explanation for deference because, as we have seen, the Court failed to take any account of the source of law (statute or regulation) being interpreted by the agency. The Court, instead, rested its theory of deference on functionalism: courts should defer to an agency's interpretation of a statute because of the agency's expertise and experience in administering the legal regime. ${ }^{65}$ Regarding an agency interpretation of its regulations, the Court appeared to have accepted only an a fortiori rationale for the rule of deference: a court defers to an agency's interpretation of a statute, so of course a court defers to an agency's interpretation of the regulations the agency itself has promulgated pursuant to that statute. ${ }^{66}$

64. See Decker v. Nw. Envtl. Def. Ctr., 133 S. Ct. 1326, 1339 (2013) (Scalia, J., concurring in part and dissenting in part) ("For decades, and for no good reason, we have been giving agencies the authority to say what their rules mean, under the harmless-sounding banner of defer[ring] to an agency's interpretation of its own regulations." (citation omitted) (quotation marks omitted)); Manning, supra note 6, at 629 ("Perhaps because of the perceived common sense appeal of Seminole Rock deference, it took many years for the Court to offer any detailed rationale for the doctrine." (footnote omitted)).

65. See Decker, 133 S. Ct. at 1340 (Scalia, J., concurring in part and dissenting in part) (accepting that the Court has relied on functionalism to support Auer deference, but claiming that functionalism "leads to the conclusion that agencies and not courts should make regulations. But it has nothing to do with who should interpret regulations - unless one believes that the purpose of interpretation is to make the regulatory program work in a fashion that the current leadership of the agency deems effective. Making regulatory programs effective is the purpose of rule making, in which the agency uses its special expertise to formulate the best rule. But the purpose of interpretation is to determine the fair meaning of the rule - to say what the law is. Not to make policy, but to determine what policy has been made and promulgated by the agency, to which the public owes obedience." (citation omitted) (quotation marks omitted)).

66. See Manning, supra note 6, at 627 ("The conventional wisdom is that if binding deference is appropriate for agency interpretations of statutes, it is surely all the more so when agencies interpret their own regulations." (footnote omitted)). Justice Scalia has rejected the view that the Court's decisions accept an a fortiorari rationale for judicial deference to an agency's interpretations of its regulations. See Decker, 133 S. Ct. at 1340 (Scalia, J., concurring in part and dissenting in part) ("Another conceivable justification for Auer deference, though not one that is to be found in our cases, is this: If it is reasonable to defer to agencies regarding the meaning of statutes that Congress enacted, as we do per Chevron, it is a fortiori reasonable to defer to them regarding the meaning of regulations that they themselves crafted. To give an agency less control over the meaning of its own regulations than it has over the meaning of a congressionally enacted statute seems quite odd."); cf. Stephenson \& Pogoriler, supra note 19, at 1454-55 ("[T]he originalist 
Under this reasoning, to the extent source of law mattered, the fact that the agency was the source of the law weighed in favor of judicial deference to the agency's legal interpretation. The Court believed that the agency was in the best position to understand the statute, especially because the agency interpretation was contemporaneous with the enactment of the statute. The Court expected the agency's knowledge and expertise to be greater with respect to regulations that the agency itself had promulgated.

\section{B. Chevron and the Rule of Deference to an Agency's Interpretation of Its Regulations}

The Supreme Court's 1984 decision in Chevron, U.S.A., Inc. v. Natural Resources Defense Council, Inc. ${ }^{67}$ signaled the acceptance of a strong rule of deference to administrative interpretations of statutes. ${ }^{68}$

The canon of construction identified in Chevron has played a critical role in defining the relative roles of legislature, agency, and court in developing the content of public law. The canon clearly recognizes the primacy of the legislature by holding 'unambiguously expressed' congressional intent determines the content of law and 'must be given effect.' When a statute is ambiguous, however, Chevron located lawmaking primacy in the agency, whose interpretation of law must be upheld by a court unless it is unreasonable. ${ }^{6}$

In Chevron, the Court articulated a strong formal rationale for deference to an agency. Chevron's formal approach was motivated by the separation of powers: the Court would require an agency to conform to law that Congress clearly defined in a statute. ${ }^{70}$ If, however, the statute were ambiguous, the Court would defer to an agency's interpretation $^{71}$ because Congress had effectively delegated the resolution

justification for Seminole Rock is inapplicable in the Chevron context because in that setting, the interpreter (the agency) did not enact the ambiguous text in question (the statute). For this reason, some have concluded that Seminole Rock deference ought to be even more robust than Chevron deference." (footnotes omitted)).

67. 467 U.S. 837 (1984).

68. See generally Healy, supra note 1, at 15-18 (discussing the significance of the Chevron decision); see also id. at $1 \mathrm{n} .2$ (citing sources describing the significance of the Chevron decision).

69. Michael P. Healy, Spurious Interpretation Redux: Mead and The Shrinking Domain of Statutory Ambiguity, 54 ADMIN. L. REV. 673, 675 (2002) (footnotes omitted).

70. See Chevron, 467 U.S. at $842-43$.

71. See id. 
of the ambiguity to the agency. ${ }^{72}$ The Court bolstered its judgment that deference was necessary because it was Congress's intent and followed from constitutional structure. The Court concluded that the resolution of the statutory ambiguity necessitates a policy decision, which under the constitutional structure is to be made by the politically-responsive agency, rather than the nonpolitical court. ${ }^{73}$ The Court retained the functional rationale that the agency has greater experience and expertise with respect to the underlying issue as an additional, rather than central, argument for deference. ${ }^{74}$ The Court's turn to formalism interestingly ignored the APA's significance as the statutory framework for administrative law. ${ }^{75}$

In this regard, Chevron clearly distinguished between review to determine the best interpretation as contrasted with review to determine a permissible interpretation. The Court would hold the agency had acted unlawfully if the agency's interpretation conflicted with law that Congress had clearly defined, an impermissible interpretation. Chevron established that, if the agency interpretation were permissible, then a court had to accept the agency interpretation as a matter of substance, without regard to whether that interpretation was the best or the interpretation favored by the court. ${ }^{76}$ The consequence of Chevron was

72. See id. at 843-44 ("If Congress has explicitly left a gap for the agency to fill, there is an express delegation of authority to the agency to elucidate a specific provision of the statute by regulation. Such legislative regulations are given controlling weight unless they are arbitrary, capricious, or manifestly contrary to the statute. Sometimes the legislative delegation to an agency on a particular question is implicit rather than explicit. In such a case, a court may not substitute its own construction of a statutory provision for a reasonable interpretation made by the administrator of an agency." (footnotes omitted)).

73. See id. at 865-66.

74. See id. at 865 .

75. See Healy, supra note 1, at 18 \& n.114; cf. United States v. Mead Corp., 533 U.S. 218, 241 (Scalia, J., dissenting) ("There is some question whether Chevron was faithful to the text of the [APA], which it did not even bother to cite." (footnote omitted)).

76. If one were to employ Professor Strauss's nomenclature, a permissible construction is one that is within the "Chevron space." See generally Peter L. Strauss, "Deference" Is Too ConfusingLet's Call Them "Chevron Space” and "Skidmore Weight," 112 CoLuM. L. REV. 1143 (2012) [hereinafter Strauss, "Deference” Is Too Confusing]. Professor Strauss has also presented this issue as one that distinguishes between a court acting as a decider or as an overseer. Peter L. Strauss, Overseers or "The Deciders"-The Courts in Administrative Law, 75 U. CHI. L. REV. 815, 816-17 (2008) [hereinafter Strauss, Overseers or "The Deciders"].

When the court is itself the decider, determining the correct meaning of law, the court does not defer to an agency determination, although it may decide to give weight to the agency determination as the court makes its own decision about the content of law. See Strauss, "Deference" Is Too Confusing, supra at 1165 ("The lines defining an agency's Chevron space must be judicially determined, a determination that is, irreducibly, a statement of what the law is. But that unmistakably judicial determination should be informed by agency judgments in ways that have 
that there is no single, correct interpretation of an ambiguous statute. An agency may change its interpretation of an ambiguous statute because the agency's political views have changed. If that new interpretation is permissible, Chevron holds that a court must accept that different, permissible interpretation. ${ }^{77}$

During the years after the Chevron decision, the Supreme Court adhered to the strong rule of deference to agency interpretations of regulations. In the most prominent modern iteration of this rule, Auer $v$. Robbins ${ }^{78}$ Justice Scalia wrote the opinion for a unanimous Court. The Court first addressed whether the agency's regulation was foreclosed by the Fair Labor Standards Act of 1938 (FLSA). ${ }^{79}$ The Court deferred to the agency's regulations because they were a reasonable construction of an ambiguous statute. ${ }^{80}$

The Court then turned its attention to the claim that the agency had erred in its application of the regulations. The Court reasoned:

Because the salary-basis test is a creature of the Secretary's own regulations, his interpretation of it is, under our jurisprudence, controlling unless 'plainly erroneous or inconsistent with the regulation.' Robertson v. Methow Valley Citizens Council, 490 U.S. 332, 359 (1989) (quoting Bowles v. Seminole Rock \& Sand Co., 325

U.S. 410, 414 (1945)). That deferential standard is easily met here.

Two points about this passage are noteworthy. First, Justice Scalia's citations tied the modern understanding of this rule to the initial articulation of the rule in Seminole Rock. Second, Justice Scalia characterized the standard as "deferential." A standard is deferential in

been conventional at least since 1827." (footnote omitted)). If, however, the court is acting as overseer, the agency has been delegated authority by Congress to define the law and the court must decide only whether the agency interpretation is permissible and must defer to the agency's definition provided the agency is within the legal space demarcated by the ambiguity enacted by Congress. See id. at 1173 ("[E]xecutive agencies may be vested by Congress with authority to act with the force of law, so long as the boundaries of that action can be judicially determined. In that space, the agency is the prime actor, and the very conclusion that Congress has delegated authority to it commands reviewing courts to act, not as deciders, but as overseers.").

77. See Chevron, 467 U.S at 863-64. In the terminology of Professor Strauss, the agency would in such a situation, be acting within the "Chevron space." See Strauss, "Deference" Is Too Confusing, supra note 76, at 1163. The agency's decisionmaking process in explaining the substantive change would, however, be reviewed under the arbitrary or capricious review standard. See Healy, supra note 1 , at 50-51.

78. 519 U.S. 452 (1997).

79. Id. at 454 .

80. See id. at 457-58.

81. Id. at 461. 
Justice Scalia's view only when a court must accept a result even though the court may have reached a different conclusion if the court itself had the authority to resolve the matter. ${ }^{82}$ The court is concerned only with whether the agency interpretation is permissible, rather than whether it is the best interpretation.

The Court's decision in Auer is also notable because Justice Scalia did not provide any post-Chevron rationale for Seminole Rock deference. $^{83}$ Despite the fact that Chevron had presented a formal rationale for judicial deference to an agency's interpretation of a statute, Justice Scalia simply accepted the long-standing rule of deference without providing any formal rationale for it. ${ }^{84}$

One change that Chevron did not bring to the shape of Auer/Seminole Rock deference is that the Auer Court did not describe a two-step process for review. The Court instead adhered to the singlelevel standard of deference to an agency's permissible interpretation of its regulation. The Court might have taken the opportunity post-Chevron to define clearly an analytic first step, equivalent to the first step of Chevron, at which the Court determines whether the regulation is clear in its requirements.

Defining the review standard in that way would not have been

82. Justice Scalia's understanding of the nature of proper deference is apparent when one accounts for his view of judicial review under the Skidmore standard. See Kasten v. Saint-Gobain Performance Plastics Corp., 131 S. Ct. 1325, 1340 n.6 (2011) (Scalia, J., dissenting) ("In my view this [Skidmore-deference] doctrine (if it can be called that) is incoherent, both linguistically and practically. To defer is to subordinate one's own judgment to another's. If one has been persuaded by another, so that one's judgment accords with the other's, there is no room for deferral — only for agreement. Speaking of 'Skidmore deference' to a persuasive agency position does nothing but confuse."); Strauss, "Deference” Is Too Confusing, supra note 76, at 1145 ("'Skidmore weight' addresses the possibility that an agency's view on a given statutory question may in itself warrant respect by judges who themselves have ultimate interpretive authority."); see also Lisa Schultz Bressman, How Mead Has Muddled Judicial Review of Agency Action, 58 VAND. L. REV. 1443, 1467 (2005) ('Skidmore deference, though phrased as 'deference,' actually allocates interpretive control to courts." (footnote omitted)).

This article will refer to Skidmore review, rather than to Skidmore deference, in order to avoid the confusion that may result from the Court's continued use of the deference misnomer in this context.

83. Cf. Decker v. Nw. Envtl. Def. Ctr., 133 S. Ct. 1326, 1339 (2013) (Scalia, J., concurring in part and dissenting in part) ("For decades, and for no good reason, we have been giving agencies the authority to say what their rules mean ....").

84. Justice Scalia failed to provide a formalism-grounded rule of deference despite the fact that Professor John Manning, a former law clerk to Justice Scalia, had written a strong critique of Seminole Rock deference. See Manning, supra note 6. Justice Scalia may not have provided a formal rationale because he may not have approved of the formal frame that earlier post-Chevron decisions had placed around Seminole Rock deference. This formal rationale for Seminole Rock deference is discussed infra at notes 106-28 and accompanying text. 
surprising. Old and respected Supreme Court decisions establish the requirement that an agency must comply with its own regulations. ${ }^{85}$ The Court has supplemented this foundational rule by holding that an agency's interpretation of a regulation may not change the regulation: an agency may modify a regulation only by amending the regulation through the rule making process. ${ }^{86}$ Moreover, a change to a two-step regime would also have emphasized the significance of the status of a regulation as law, to which a court must defer under Chevron, and which binds an agency until the agency amends that law by conforming to the informal rule making process prescribed by $\S 553$ of the APA. ${ }^{87}$

The Court's failure to identify a first step in its review of an agency's interpretation of regulations has resulted in occasional confusion about whether the court is deferring to the agency's interpretation or simply finding the law clearly defined by the regulations. ${ }^{88}$ The failure has also contributed to the fact that "little law or considered practice on interpretive methodology applicable to regulations is developing." 89

In other post-Chevron decisions, the Court has directly stated its understanding that the Auer/Seminole Rock standard is properly deferential-in Professor Strauss's nomenclature ${ }^{90}$ the court is acting as overseer, rather than decider. In Thomas Jefferson University $v$. Shalala, ${ }^{91}$ the Court considered whether the Secretary of Health and Human Services had erred in her interpretation of Medicare regulations. $^{92}$ When the Court defined the standard of review, its articulation was very close to the Chevron standard: The Court is not providing its own preferred interpretation - the best interpretation-of the legal text, but is rather deciding only whether the agency interpretation is permissible, that is, within the space defined by the legal text-here, regulations. ${ }^{93}$ The Thomas Jefferson University Court stated:

85. See Vitarelli v. Seaton, 359 U.S. 535, 545 (1959); United States ex rel. Accardi v. Shaughnessy, 347 U.S. 260, 267 (1954).

86. See Shalala v. Guernsey Mem'l Hosp., 514 U.S. 87, 100 (1995).

87. 5 U.S.C. $\S 553$ (2012).

88. For an example of this confusion, see the discussion of Seminole Rock, supra at notes 31-43 and accompanying text.

89. See Stack, supra note 6, at 360 ("Indeed, it is hard to avoid the impression that the judiciary does not recognize regulatory interpretation as an aspect of judicial practice, like statutory interpretation, that merits independent and systematic consideration." (footnote omitted)).

90. See Strauss, Overseers or "The Deciders", supra note 76.

91. 512 U.S. 504 (1994).

92. Id. at 506 .

93. Id. at 512 . 
We must give substantial deference to an agency's interpretation of its own regulations. Martin v. Occupational Safety and Health Review Comm'n, 499 U.S. 144, 150-151 (1991); Lyng v. Payne, 476 U.S. 926, 939 (1986); Udall v. Tallman, 380 U.S. 1, 16 (1965). Our task is not to decide which among several competing interpretations best serves the regulatory purpose. Rather, the agency's interpretation must be given 'controlling weight unless it is plainly erroneous or inconsistent with the regulation.' Ibid. (quoting Bowles v. Seminole Rock \& Sand Co., 325 U.S. 410, 414 (1945)). In other words, we must defer to the Secretary's interpretation unless an 'alternative reading is compelled by the regulation's plain language or by other indications of the Secretary's intent at the time of the regulation's promulgation.' Gardebring v. Jenkins, 485 U.S. 415,430 (1988). ${ }^{94}$

In addition to stating that the Auer and Chevron review standards have the same legal effect, the Court has on at least one occasion directly relied on the Chevron precedent when reviewing an agency's interpretation of a regulation, rather than a statute. In Pauley $v$. BethEnergy Mines, Inc., ${ }^{95}$ the Court considered whether the Secretary of Labor's interpretation of regulations governing the award of black lung benefits was lawful. ${ }^{96}$ The Court stated that it had to "decide whether this position is reasonable." 97 The Court thereafter stated its conclusion in terms that were very similar to its reasoning in Thomas Jefferson University:

While it is possible that the claimants' parsing of these impenetrable regulations would be consistent with accepted canons of construction, it is axiomatic that the Secretary's interpretation need not be the best or most natural one by grammatical or other standards. EEOC $v$. Commercial Office Products Co., 486 U.S. 107, 115 (1988). Rather, the Secretary's view need be only reasonable to warrant deference. Ibid.

The Court's willingness to equate Chevron deference with Auer/Seminole Rock deference is reinforced by the Court's citation to the Commercial Office Products decision. That case involved review of an agency's interpretation of a statute, not a regulation. ${ }^{99}$ The BethEnergy

94. Id.

95. 501 U.S. 680 (1991).

96. Id. at 699-700.

97. Id. at 699 (citing Chevron, U.S.A., Inc. v. Natural Res. Def. Council, Inc., 467 U.S. 837, 845 (1984)).

98. Id. at 702 (citation omitted).

99. EEOC v. Commercial Office Prods. Co., 486 U.S. 107, 122 (1988). 
Mines Court's post-Chevron understanding of this rule of deference was identical to the understanding of the pre-Chevron Tallman Court: ${ }^{100}$ the rule of deference to an agency interpretation of its regulations is the same as the rule of deference to an agency interpretation of statutes.

Justice Scalia dissented in BethEnergy Mines, concluding that the regulations had a determinate meaning that conflicted with the agency interpretation. ${ }^{101}$ Justice Scalia agreed, however, that Chevron was the proper deference regime applicable to review agency interpretation of regulations, provided that the regulations were actually ambiguous. ${ }^{102}$ He disagreed with the majority that, under Chevron, deference to the particular agency that had made the interpretation was proper. ${ }^{103}$ In sum, as Chevron came to be the new paradigm for deference to agency interpretations of statutes, the Court also understood Chevron as the appropriate standard of review for agency interpretations of regulations.

Although Justice Scalia failed to present any rationale in Auer, including a formal rationale, for Seminole Rock deference, the Court included a more formal explanation for deference in several other postChevron decisions. We have seen that, prior to the emergence of the Chevron regime, the Court's rationale for Seminole Rock deference was functional-a court defers to an agency because the agency has greater expertise and experience. ${ }^{104}$ The Court also opined that Seminole Rock deference simply followed from the broader rule of deference to an agency's interpretation of a statute. ${ }^{105}$ In the period after Chevron, the Court explained the Auer deference rule in more formal terms that were similar to its explanation of Chevron deference.

The BethEnergy Mines Court, which had relied on Chevron deference in reviewing the agency's interpretation of black lung regulations, also employed the Chevron rationale-that a court must defer to an agency when the agency exercises the power to make law that has been delegated by the legislature - to an agency's interpretation of its regulations. The Court viewed such an interpretation as another type of agency gap filling in implementing an ambiguous statute. The Court

\footnotetext{
100. See supra notes 58-66 and accompanying text.

101. See BethEnergy Mines, 501 U.S. at 707 (Scalia, J., dissenting).

102. See id. at 707-08.

103. See id. at 707 (Scalia, J., dissenting) ("But even if the regulations were ambiguous, it would not follow that the Secretary of Labor is entitled to deference. Nothing in our Chevron jurisprudence requires us to defer to one agency's interpretation of another agency's ambiguous regulations.").

104. See supra notes 50-53 and accompanying text.

105. See supra notes 60-62 and accompanying text.
} 
stated:

As Chevron itself illustrates, the resolution of ambiguity in a statutory text is often more a question of policy than of law. When Congress, through express delegation or the introduction of an interpretive gap in the statutory structure, has delegated policy-making authority to an administrative agency, the extent of judicial review of the agency's policy determinations is limited. ${ }^{106}$

The Court's deference to the Department of Labor's interpretation of regulations again reflected a convergence of the functionalism of agency expertise $^{107}$ and the formalism of conformance to legislative supremacy:

The [Black Lung] Benefits Act has produced a complex and highly technical regulatory program. The identification and classification of medical eligibility criteria necessarily require significant expertise and entail the exercise of judgment grounded in policy concerns. In those circumstances, courts appropriately defer to the agency entrusted by Congress to make such policy determinations .... .

That Congress intended in the [black lung program] to delegate to the Secretary of Labor broad policymaking discretion in the promulgation of her interim regulations is clear from the text of the statute and the history of this provision. Congress declined to require that the DOL adopt the HEW interim regulations verbatim. Rather, the delegation of authority requires only that the DOL's regulations be 'not... more restrictive than' HEW's. Further, the delegation was made with the intention that the program evolve as technological expertise matured. $^{108}$

\section{The Court then reiterated its view:}

As delegated by Congress, then, the Secretary's authority to promulgate interim regulations 'not... more restrictive than' the HEW interim

106. BethEnergy Mines, 501 U.S. at 696 (citations omitted).

107. The functional rationale for deference has been reiterated in other post-Chevron cases. E.g., Thomas Jefferson Univ. v. Shalala, 512 U.S. 504, 512 (1994) ("This broad deference [to an agency interpretation of regulations] is all the more warranted when, as here, the regulation concerns a complex and highly technical regulatory program, in which the identification and classification of relevant criteria necessarily require significant expertise and entail the exercise of judgment grounded in policy concerns." (citations omitted) (quotation marks omitted)); Shalala v. Guernsey Mem’l Hosp., 514 U.S. 87, 108 (1995) (O’Connor, J., dissenting) ("I take seriously our obligation to defer to an agency's reasonable interpretation of its own regulations, particularly when, as here, the regulation concerns a complex and highly technical regulatory program, in which the identification and classification of relevant criteria necessarily require significant expertise and entail the exercise of judgment grounded in policy concerns." (citations omitted) (quotation marks omitted)).

108. BethEnergy Mines, 501 U.S. at 697. 
regulations necessarily entails the authority to interpret HEW's regulations and the discretion to promulgate interim regulations based on a reasonable interpretation thereof. From this congressional delegation derives the Secretary's entitlement to judicial deference.

This rationale, the inferred intent of Congress regarding judicial deference to an agency, is a restatement of the Chevron Court's rationale for deference. ${ }^{110}$ This rationale is also in accord with the Court's broad and long-standing view that Congress has authority to prescribe the standards for judicial review. ${ }^{11}$

The Court provided a similar rationale for Auer deference in Martin v. Occupational Safety and Health Review Commission (OSHRC). ${ }^{112}$

109. Id. at 698. Justice Scalia dissented from the Court's decision, concluding that the regulations had a determinate meaning and were therefore unambiguous. See id. at 707 ("In my view the HEW regulations referred to by the present statute are susceptible of only one meaning, although they are so intricate that that meaning is not immediately accessible."). This was only part of the reason for Justice Scalia's dissent. He also concluded that the majority was according deference to the wrong agency, even assuming that the regulations were ambiguous. Id. He did, however, agree with the Court that Chevron was otherwise the proper regime of deference to consider:

But even if the regulations were ambiguous, it would not follow that the Secretary of Labor is entitled to deference. Nothing in our Chevron jurisprudence requires us to defer to one agency's interpretation of another agency's ambiguous regulations. We rejected precisely that proposition in Martin v. Occupational Safety and Health Review Comm'n, 499 U.S. 144 (1991), in holding that the Occupational Safety and Health Review Commission (OSHRC) was not entitled to deference in interpreting the Secretary of Labor's regulations. Having used Chevron to rebuff OSHRC's incursions there, it seems a bit greedy for the Secretary to use Chevron to launch the DOL's own cross-border attack here. In my view, the only legitimate claimant to deference with regard to the present regulations is the agency that drafted them. Id. at 707-08.

110. See Chevron, U.S.A., Inc. v. Natural Res. Def. Council, Inc., 467 U.S. 837, 843-44 (1984) ("If Congress has explicitly left a gap for the agency to fill, there is an express delegation of authority to the agency to elucidate a specific provision of the statute by regulation. Such legislative regulations are given controlling weight unless they are arbitrary, capricious, or manifestly contrary to the statute. Sometimes the legislative delegation to an agency on a particular question is implicit rather than explicit. In such a case, a court may not substitute its own construction of a statutory provision for a reasonable interpretation made by the administrator of an agency." (footnotes omitted)); see also Manning, supra note 6, at 627 ("Seminole Rock, like Chevron, treats the agency's interpretation as binding; it adopts the form of deference that necessarily rests on the idea that Congress has delegated to the agency authority to construe its own regulations." (footnote omitted)); Stack, supra note 6, at 410 ("Like Chevron, Seminole Rock deference is grounded in an attitude of judicial deference to the agency's expertise, accountability, and a presumption of delegation." (footnote omitted)).

111. See Adams Fruit Co. v. Barrett, 494 U.S. 638, 649 (1990) ("A precondition to deference under Chevron is a congressional delegation of legislative authority."); Chevron, 467 U.S. at $843-$ 44; Skidmore v. Swift \& Co., 323 U.S. 134, 139 (1944) ("There is no statutory provision as to what, if any, deference courts should pay to the Administrator's conclusions.").

112. 499 U.S. 144 (1991). 
There, the Court had to determine what deference was owed to two different agencies that shared responsibility for implementing the Occupational Safety and Health Act. ${ }^{113}$ The issue arose regarding an interpretation of a regulation promulgated by the Labor Department. ${ }^{114}$ That Department's interpretation of the regulation differed from the interpretation of the OSHRC, ${ }^{115}$ the agency that adjudicated regulatory violations. ${ }^{116}$

The Court framed the issue as one that is resolved by a determination of congressional intent. ${ }^{117}$ This framing is consistent with the Court's broad view of deference: Congress defines the deference that is due to an agency either expressly or by inference. ${ }^{118}$ The Martin Court's unanimous conclusion was grounded in the inference that Congress intended that a court would defer to the agency that has the greater expertise and experience regarding the matter being interpreted:

Although the Act does not expressly address the issue, we now infer from the structure and history of the statute that the power to render authoritative interpretations of OSH Act regulations is a "necessary adjunct' of the Secretary's powers to promulgate and to enforce national health and safety standards. The Secretary enjoys readily identifiable structural advantages over the Commission in rendering authoritative interpretations of OSH Act regulations. Because the Secretary promulgates these standards, the Secretary is in a better position than is the Commission to reconstruct the purpose of the regulations in question. Moreover, by virtue of the Secretary's statutory role as enforcer, the Secretary comes into contact with a much greater number of regulatory problems than does the Commission, which encounters only those regulatory episodes resulting in contested citations. Consequently, the Secretary is more likely to develop the expertise relevant to assessing the effect of a particular regulatory interpretation. Because historical familiarity and policymaking expertise account in the first instance for the presumption that Congress delegates interpretive lawmaking power to the agency rather than to the reviewing court, we presume here that Congress intended to invest

\footnotetext{
113. Id. at $146-47$.

114. Id. at 148 .

115. Id. at 146 .

116. Id. at $152-53$.
}

117. See id. at 151 ("Because applying an agency's regulation to complex or changing circumstances calls upon the agency's unique expertise and policymaking prerogatives, we presume that the power authoritatively to interpret its own regulations is a component of the agency's delegated lawmaking powers. The question before us in this case is to which administrative actorthe Secretary or the Commission-did Congress delegate this 'interpretive' lawmaking power under the OSH Act." (citation omitted) (footnote omitted)).

118. See United States v. Mead Corp., 533 U.S. 218, 221 (2001). 
interpretive power in the administrative actor in the best position to develop these attributes.

The Martin Court's consideration of the deference issue also focused on the agency's delegated lawmaking authority. The Court concluded that Congress intended judicial deference to an agency only when the agency possessed lawmaking power delegated by Congress. ${ }^{120}$ Moreover, the Court reasoned that an agency adjudication constitutes lawmaking only when Congress has delegated to an agency the power to make law:

Within traditional agencies - that is, agencies possessing a unitary structure - adjudication operates as an appropriate mechanism not only for factfinding, but also for the exercise of delegated lawmaking powers, including lawmaking by interpretation. But in these cases, we concluded that agency adjudication is a generally permissible mode of law-making and policymaking only because the unitary agencies in question also had been delegated the power to make law and policy through rule making. Insofar as Congress did not invest the Commission with the power to make law or policy by other means, we cannot infer that Congress expected the Commission to use its adjudicatory power to play a policymaking role. Moreover, when a traditional, unitary agency uses adjudication to engage in lawmaking by regulatory interpretation, it necessarily interprets regulations that it has promulgated. This, too, cannot be said of the Commission's power to adjudicate.

Consequently, we think the more plausible inference is that Congress intended to delegate to the Commission the type of nonpolicymaking adjudicatory powers typically exercised by a court in the agency-review context. Under this conception of adjudication, the Commission is authorized to review the Secretary's interpretations only for consistency with the regulatory language and for reasonableness. In addition, of course, Congress expressly charged the Commission with making authoritative findings of fact and with applying the Secretary's standards to those facts in making a decision. The Commission need be viewed as possessing no more power than this in order to perform its statutory role as 'neutral arbiter.'

Given this reasoning, the Court concluded that it would give

119. Martin, 499 U.S. at $152-53$ (citations omitted).

120. See id. at 151 ("Because applying an agency's regulation to complex or changing circumstances calls upon the agency's unique expertise and policymaking prerogatives, we presume that the power authoritatively to interpret its own regulations is a component of the agency's delegated lawmaking powers." (citation omitted)).

121. Id. at 154-55 (citations omitted). 
Chevron-like deference to the Department of Labor's interpretation of the regulation that the Department had promulgated. ${ }^{122}$ The Court viewed such deference as proper even when the agency's interpretation was presented in the agency's "litigating position." 123 The Martin Court stated, finally, that OSHRC's interpretations "are still entitled to some weight on judicial review."124 One of the cases cited to support this conclusion was Skidmore, ${ }^{125}$ thereby adumbrating the Court's decision in Mead to bifurcate deference to interpretations of a statute between the Chevron and Skidmore approaches.

Martin thus presented an understanding of Auer deference that was consistent with Chevron deference. The Court did not abandon the longstanding functional rationale for such deference, that an agency interpretation is presumptively proper because the agency is more knowledgeable and experienced than a court about the issue being resolved. ${ }^{126}$ Rather, the Court placed a formal frame around that rationale: a court defers because Congress intended that the expert agency, rather than the generalist court, would make legal determinations when the statute itself did not resolve the matter. This rationale echoed the earlier a fortiorari rationale, ${ }^{127}$ because it made no legal distinction between different types of legal interpretations. In the Court's view, Congress intended judicial deference regardless of whether the agency interpreted a statute or its regulation. ${ }^{128}$

122. See id. at 156-57. Professors Stephenson and Pogoriler point out that the Martin Court missed a clear opportunity to address the separation of powers concerns that undermine Auer deference, because the Court accepted the Department's role in writing the regulation as an important reason for deferring to that agency's interpretation. See Stephenson \& Pogoriler, supra note 19, at 1502-03 ("Martin missed an opportunity to remedy the self-delegation problem that is usually inherent in Seminole Rock, but that can be avoided in vertical split-enforcement systems.").

123. See Martin, 499 U.S. at 157 ("The Secretary's interpretation of OSH Act regulations in an administrative adjudication ... is agency action, not a post hoc rationalization of it. Moreover, when embodied in a citation, the Secretary's interpretation assumes a form expressly provided for by Congress. See 29 U.S.C. § 658. Under these circumstances, the Secretary's litigating position before the Commission is as much an exercise of delegated lawmaking powers as is the Secretary's promulgation of a workplace health and safety standard.”).

124. Id.

125. Id.

126. See Manning, supra note 6, at 630 ("[T] deference particularly justified because of the agency's superior competence to understand and explain its own regulatory text." (footnote omitted)).

127. This rationale is described supra at notes 60-66 and accompanying text.

128. In this regard, the Court did not see any need to distinguish between the agency as lawmaker (in promulgating regulations) and as law executor (in applying the regulations in individual cases). 


\section{Conclusion}

In sum, Chevron had only a limited impact on the Court's application and understanding of Seminole Rock deference. The Court understood the two standards as equivalent in granting deference to an agency's permissible interpretation of the law being interpreted regardless of its status as statute or regulation. Chevron's articulation of a formal rationale for deference did have a modest effect on the stated rationale for what came to be called Auer deference. After Chevron, the Court added to its purely functional explanation of this deference the formal legislative supremacy claim that Congress intended that courts would defer to an agency's interpretation of its regulations. ${ }^{129}$

We turn now to the development of the law following the Court's decision in Mead. That decision, which reshaped the scope of Chevron deference, ${ }^{130}$ has also had a significant impact on the unsettled present of Auer deference, an impact discussed in the next part of this article.

\section{THE UNCERTAIN PRESENT: AUER DEFERENCE IN THE AFTERMATH OF $M E A D$}

During the last several years, the Supreme Court has decided a quintet of cases in which the Court has abandoned the long-standing, reflexive use of Auer deference. The Court appears to be ever more skeptical of Auer deference. This new skepticism can be traced to the Supreme Court's 2001 decision in United States v. Mead Corp. ${ }^{131}$ Mead established that, when a court reviews an agency interpretation of an ambiguous statute, the court will employ one of two standards: Chevron deference or Skidmore review. ${ }^{132}$ The proper standard of review depends on the source of the law being reviewed:

The key judicial determination yielded by this [Mead] step is the identification of the source of the law that the court is reviewing. That source is either the agency itself, when the agency has exercised lawmaking power delegated to it by Congress [triggering Chevron deference], or Congress, when the agency has simply decided what it believes the ambiguous statute means in the particular setting for the agency's decision [triggering Skidmore review]. Mead established...

\footnotetext{
129. See supra notes 106-28 and accompanying text.

130. See Healy, supra note 1, at 1-2.

131. 533 U.S. 218 (2001).

132. Id. at $236-37$.
} 
that there are two requirements for an agency to be seen as the source of lawmaking power: Congress must have delegated lawmaking power to the agency and the agency must actually have exercised that delegated lawmaking power. The agency must have been able to make law and must have intended to make law. In the absence of an agency properly making law, Congress itself is the source of the law. ${ }^{13}$

The Supreme Court's decision in Mead has affected not only the scope of application of Chevron deference, but has revived review under the much-older Skidmore regime. Mead's impact can now be seen as extending to and changing the Court's understanding of Auer deference.

\section{A. Source of Law as a Limit on Auer Deference: Gonzales v. Oregon}

One might have anticipated that the source of law consideration, so important in Mead, would have no applicability in the Auer context. Because the agency is interpreting a regulation previously promulgated by the agency itself, the agency would surely be the source of the law, thereby triggering Chevron-style deference. ${ }^{134}$

In Gonzales v. Oregon, ${ }^{135}$ however, the Court applied a source-oflaw analysis in limiting the scope of Auer deference. There, the Court reviewed "whether the Controlled Substances Act allows the United States Attorney General to prohibit doctors from prescribing regulated drugs for use in physician-assisted suicide, notwithstanding a state law permitting the procedure." 136 The Oregon Court initially summarized the law of deference to an agency that at the least equated Auer deference with Chevron deference, while also expressing the limitations on the scope of Chevron deference defined by Mead. ${ }^{137}$

133. Healy, supra note 1 , at 40 (footnotes omitted).

134. Indeed, the Martin Court concluded that the Department of Labor would receive Auer deference because that agency had promulgated the regulations being interpreted. See supra notes $120-23$ and accompanying text.

135. 546 U.S. 243 (2006).

136. Id. at $248-49$.

137. See id. at 255-56, where the Court stated:

Although balancing the necessary respect for an agency's knowledge, expertise, and constitutional office with the courts' role as interpreter of laws can be a delicate matter, familiar principles guide us. An administrative rule may receive substantial deference if it interprets the issuing agency's own ambiguous regulation. Auer v. Robbins, 519 U.S. 452, 461-463 (1997). An interpretation of an ambiguous statute may also receive substantial deference. Chevron U.S.A. Inc. v. Natural Resources Defense Council, Inc., 467 U.S. 837, 842-845 (1984). Deference in accordance with Chevron, however, is warranted only 'when it appears that Congress delegated authority to the agency generally to make rules carrying the force of law, and that the agency interpretation 
The Court then concluded that the regulations the Attorney General interpreted in Oregon were simply a restatement of statutory text and therefore constituted law defined by Congress, rather than law defined by the agency acting pursuant to delegated lawmaking power. ${ }^{138}$ The Court accordingly held that, because the interpretation being challenged in the case was, in fact, an interpretation of the statute, the Auer regime did not apply:

The regulation uses the terms 'legitimate medical purpose' and 'the course of professional practice,' ibid., but this just repeats two statutory phrases and attempts to summarize the others. It gives little or no instruction on a central issue in this case: Who decides whether a particular activity is in 'the course of professional practice' or done for a 'legitimate medical purpose'? Since the regulation gives no indication how to decide this issue, the Attorney General's effort to decide it now cannot be considered an interpretation of the regulation. Simply put, the existence of a parroting regulation does not change the fact that the question here is not the meaning of the regulation but the meaning of the statute. An agency does not acquire special authority to interpret its own words when, instead of using its expertise and experience to formulate a regulation, it has elected merely to paraphrase the statutory language.

Rather, the conditional, post-Mead deference regime for review of an agency interpretation of a statute applied. ${ }^{140}$ The Court held that the interpretation of the statute was unlawful, applying the Skidmore-review standard. ${ }^{141}$

The Supreme Court's decision in Gonzales v. Oregon is notable in several respects. The case reinforces the lessons of Mead by confirming the significance of the source of law in determining the applicable standard of review. Congress, rather than the agency, was actually the source of the law being interpreted. Mead instructs that a court does not

claiming deference was promulgated in the exercise of that authority.' United States $v$. Mead Corp., 533 U.S. 218, 226-227 (2001). Otherwise, the interpretation is 'entitled to respect' only to the extent it has the 'power to persuade.' Skidmore v. Swift \& Co., 323 U.S. 134, 140 (1944).

138. See id. at 257 ("[T]he underlying regulation does little more than restate the terms of the statute itself. The language the Interpretive Rule addresses comes from Congress, not the Attorney General, and the near equivalence of the statute and regulation belies the Government's argument for Auer deference.").

139. Id. (emphasis added).

140. See id. at 258 ("Deference under Auer being inappropriate, we turn to the question whether the Interpretive Rule, on its own terms, is a permissible interpretation of the [Controlled Substances Act].").

141. See id. at 269. 
defer to an agency when Congress is the source of the law being interpreted, rather than the agency. ${ }^{142}$

The decision also accepts the long-standing view that Auer deference is proper deference, pursuant to which a court must accept a reasonable (that is, permissible) agency interpretation. Auer deference is, in the Court's view, analogous to Chevron deference. Because the agency was not itself the source of the law being interpreted, however, such deference was not appropriate.

Finally, the Court's analysis in Oregon recognizes that the Skidmore review regime contrasts sharply with Auer deference. Under Skidmore, the court, rather than the agency, exercises interpretive authority and determines the meaning of the ambiguous law being interpreted. ${ }^{143}$ The agency's role is limited only to convincing the court that the agency's interpretation ought to be adopted by the court, because the agency's interpretation is persuasive-persuasive, but not binding when it is reasonable.

\section{B. A Broader, Although Unintended, Practical Consequence of Mead: Coeur Alaska, Inc. v. Southeast Alaska Conservation Council}

Three years after the Oregon decision, the Court considered Auer deference again in Coeur Alaska, Inc. v. Southeast Alaska Conservation Council (SEACC). ${ }^{144}$ There, the Court reviewed how the Environmental Protection Agency (EPA) had applied the Clean Water Act to a plan by Coeur Alaska, a mining company, "to put 4.5 million tons of tailings in [a] lake. This [would] raise the lakebed 50 feet-to what is now the lake's surface - and [would] increase the lake's area from 23 to about 60 acres." 145 Coeur Alaska had received a permit under section $404^{146}$ from the U.S. Army Corps of Engineers to fill the lake with the mine

142. Oregon also eliminated the incentive for an agency to gain deference by incorporating ambiguous statutory text in its regulations. See Stephenson \& Pogoriler, supra note 19, at 1464 ("[A]n agency confronted with a statutory ambiguity might try to bootstrap its way into the equivalent of Chevron deference by promulgating a legislative rule that preserves or restates the statutory ambiguity, and then issuing an interpretive rule that purports to interpret not the statute, but the regulation. If Seminole Rock is applied in such cases, it would be quite easy for agencies to circumvent Mead.").

143. Skidmore review is contrasted with Chevron deference supra at notes 82, 132-33 and accompanying text. The nature of a court's role when reviewing under the Skidmore regime is also discussed in Healy, supra note 1, at 46-49.

144. 557 U.S. 261 (2009).

145. Id. at $267-68$.

146. 33 U.S.C. $\$ 1344$ (2012). 
tailings. ${ }^{147}$ The EPA had not vetoed the section 404 permit as authorized by section $404(\mathrm{c})$ of the Clean Water Act. ${ }^{148}$

SEACC argued that the mining company's activities were subject to the section $306^{149}$ requirement that any new source of pollution discharged into waters of the United States comply without exception to new source effluent limitations. ${ }^{150}$ The EPA had promulgated new source effluent limitations for froth-flotation gold mines, the category of sources into which the Coeur Alaska plant fell. SEACC argued that those standards must apply to Coeur Alaska's planned mining operations, rather than the section 404 permit allowing the filling of the lake. ${ }^{151}$

The majority first concluded that the Clean Water Act itself was ambiguous regarding the interaction of section 404 and section $306 .{ }^{152}$ The majority also concluded that the regulations promulgated by EPA were ambiguous regarding this interaction. ${ }^{153}$

Having so far discerned only ambiguity, the majority turned to the agency's interpretation of its regulations. That interpretation was presented in a memorandum prepared in 2004 by the EPA's Director of the Office of Wetlands, Oceans and Watersheds. ${ }^{154}$ The question then arose about which deference regime to apply to this interpretation of the regulations. Applying the Mead analysis, the Court summarily stated its conclusion that Chevron deference did not apply because the 2004 memorandum was "not subject to sufficiently formal procedures to merit Chevron deference." 155 The Court then stated that the memorandum "is entitled to a measure of deference because it interprets the agencies' own

\footnotetext{
147. See Coeur Alaska, 557 U.S. at 268.

148. See id. at 270 (discussing EPA's failure to act under 33 U.S.C. $§ 1344(c)$ ).

149. 33 U.S.C. $\S 1316$ (2012).

150. See Coeur Alaska, 557 U.S. at 271.

151. See id.

152. Id. at 281 ("The CWA is ambiguous on the question whether $\S 306$ applies to discharges of fill material regulated under $\S 404$."). Justice Ginsburg, writing for three dissenters, concluded that the statute clearly required that section 306 trumped section 404 because the former provision applied without limit to new sources. Id. at 301. The dissent also argued that, even if the statute were ambiguous, clear statement rules required that the Clean Water Act clearly provide that section 404 trump the more stringent effluent limits required by section 306. Id. at 303-04. The dissenters argued that, in the absence of such clarity - clarity that the majority did not claim - the statute had to be read to preclude section 404 permitting. See id. at 304.

153. See id. at 282 ("The regulations, like the statutes, do not address the question whether $\S 306$, and the EPA new source performance standards promulgated under it, apply to $§ 404$ permits and the discharges they authorize.").

154. Id. at 283. The government reiterated this interpretation in the litigation. See id. at 274.

155. Id. at 283-84 (citation to Mead omitted).
} 
regulatory scheme. See Auer, supra, at $461 \ldots$...156 This statement and the citation to Auer indicated - in sharp contrast to the Court's broad view of Auer deference in Oregon ${ }^{157}$ - the Court's view that Auer deference differs from and is less deferential than Chevron deference.

In addition to this surprising statement indicating the more limited nature of Auer deference, the Court's analysis of the permissibility of the agency's interpretation was quite close, with the Court presenting no less than five specific reasons why the interpretation was reasonable. ${ }^{158}$ The Court's analysis suggested strongly that, although it was making its own decision about the meaning of the regulations, the Court was willing to be convinced by the agency's views. ${ }^{159}$ This is the essence of Skidmore review, rather than Chevron deference. ${ }^{160}$

The similarity between the Court's review of the agency interpretation in Coeur Alaska and Skidmore review is reinforced by the Court's consideration of SEACC's contention that the Court should reject the agency's interpretation because the agency's interpretation had changed. ${ }^{161}$ The Court did not take the approach of the Chevron deference regime and simply state that an agency's change in position is irrelevant to the deference that is owed. ${ }^{162}$ Rather, the Court concluded, after close analysis, that the agency had not changed its position. ${ }^{163}$ The negative implication of the Court's analysis is that the Court may not have reached the same conclusion about the permissibility of the agency's position if the agency had changed its position.

The Court's analysis begs the question: Why would the Court apply Auer deference in a less deferential manner. The simplest explanation is that, because the Court had specifically determined that Chevron

156. Id. at 284 (emphasis added).

157. See supra note 137 and accompanying text.

158. See Coeur Alaska, 557 U.S. at 284-86.

159. See id. at 286 ('The Regas Memorandum's interpretation of the agencies' regulations is consistent with the regulatory scheme as a whole. The Memorandum preserves a role for the EPA's performance standards; it guards against the possibility of evasion of those standards; it employs the Corps' expertise in evaluating the effects of fill material on the aquatic environment; it does not allow toxic pollutants to be discharged; and we have been offered no better way to harmonize the regulations. We defer to the EPA's conclusion that its performance standard does not apply to the initial discharge of slurry into the lake but applies only to the later discharge of water from the lake into the downstream creek.").

160. See Healy, supra note 1, at 46-47.

161. See Coeur Alaska, 557 U.S. at 288-89.

162. See Healy, supra note 1 , at $50-51$.

163. See Coeur Alaska, 557 U.S. at 290-91. Indeed, the Court concluded that the agency had in its "published statements . . . adhere[d] to" its interpretation. Id. at 290. 
deference did not apply, ${ }^{164}$ the Court thought it was simply natural and appropriate to accord less deference to this informal interpretation. The same result would have occurred had the agency interpreted the statute and Skidmore review had applied.

This view that the Court was effectively saying, "Mead made me do it," when it gave only limited deference to the agency interpretation of the regulations, was presented by Justice Scalia's concurrence. Justice Scalia, the lone voice on the Court decrying the decision in Mead, ${ }^{165}$ believed that Mead had caused the Court to define a new regime for review because the Court had limited the scope of Chevron deference. ${ }^{166}$ Justice Scalia believed, however, that the Coeur Alaska Court was actually applying the Chevron regime and that there was no reason to pretend otherwise. ${ }^{167}$ Justice Scalia did not remark, contrary to the view expressed above, that the Court had changed its application of Auer deference so that it was not equivalent to Chevron deference, which Mead indicated was not due. ${ }^{168}$

In sum, Coeur Alaska suggested that Mead's impact would prove to be broader than initially indicated. If the Mead analysis determined that an agency interpretation must not receive Chevron deference, the Court ought not to apply Chevron-equivalent deference by another name. The Court accordingly reshaped its understanding of Auer deference. This deference regime, which had long been understood to be equivalent to Chevron deference, was now understood by the Coeur Alaska Court as different and less deferential than Chevron. This new understanding of Auer deference sharply contrasts with the Court's understanding in Oregon.

This new-style Auer deference takes account of an agency's change

164. See id. at 284.

165. See United States v. Mead Corp., 533 U.S. 218, 239 (2001) (Scalia, J., dissenting).

166. See Coeur Alaska, 557 U.S. at 296 (Scalia, J., concurring) ("It is quite impossible to achieve predictable (and relatively litigation-free) administration of the vast body of complex laws committed to the charge of executive agencies without the assurance that reviewing courts will accept reasonable and authoritative agency interpretation of ambiguous provisions. If we must not call that practice Chevron deference, then we have to rechristen the rose.").

167. See id. at 295 ("[I]f today's opinion is not according the agencies' reasonable and authoritative interpretation of the Clean Water Act Chevron deference, it is according some new type of deference-perhaps to be called in the future Coeur Alaska deference-which is identical to Chevron deference except for the name.").

168. Justice Breyer's concurrence also seemed to suggest that there is no real difference between Chevron deference and Auer deference. See id. at 292-93 ("At minimum, the EPA might reasonably read the statute and the applicable regulations as allowing the use of such material, say crushed rock, as 'fill' in some of these situations. Cf. Chevron U.S.A. Inc. v. Natural Resources Defense Council, Inc., 467 U.S. 837, 842-844 (1984); Auer v. Robbins, 519 U.S. 452, 461 (1997).”). 
of interpretive position and makes Auer deference equivalent to Skidmore review, which is not deference at all. This new understanding does, however, conform to the dictates of Mead by declining to give proper deference to an agency interpretation that is not itself the agency's exercise of delegated lawmaking power.

C. A New Content for Auer Deference: Talk America, Inc. v. Michigan Bell Telephone Co.

The next significant decision in the Supreme Court's ongoing and inconsistent reevaluation of Auer deference was Talk America, Inc. v. Michigan Bell Telephone Co. ${ }^{169}$ There, the Court reviewed how the Federal Communications Commission (FCC) had implemented a statutory requirement regarding the sharing of facilities at discounted rates by incumbent local exchange carriers (LECs) with competitive LECs. ${ }^{170}$ Incumbent LECs had prevailed before the court of appeals in their argument that the FCC had acted unlawfully when it required incumbent LECs to provide competitive LECs with access to entrance facilities at (discounted) cost-based rates. ${ }^{171}$ The FCC had imposed this requirement pursuant to its regulations implementing 47 U.S.C. $\S$ 251(c)(2). That provision requires that incumbent LECs ensure "interconnection" for customers of the competitive LECs. ${ }^{172}$

In reviewing the agency action, the Supreme Court first considered the statute and the agency regulations and concluded that both were ambiguous. ${ }^{173}$ The Court then turned its attention to the FCC's interpretation of its regulations - an interpretation that the agency had advanced in its amicus curiae brief before the Court. ${ }^{174}$ The Court introduced the Auer standard of deference by quoting from its recent decision in Chase Bank USA, N.A. v. Mc Coy: ${ }^{175}$

[W] defer to an agency's interpretation of its regulations, even in a legal brief, unless the interpretation is plainly erroneous or inconsistent

\footnotetext{
169. 131 S. Ct. 2254 (2011).

170. Id. at $2257-58$.

171. See id. at 2259.

172. 47 U.S.C. $\$ 251$ (c)(2) (2012).

173. See Talk America, $131 \mathrm{~S}$. Ct. at 2260 ("No statute or regulation squarely addresses whether an incumbent LEC must provide access to entrance facilities at cost-based rates as part of its interconnection duty under $§ 251$ (c)(2).”).

174. See id. at 2260-61.

175. 131 S. Ct. 871 (2011).
} 
with the regulation[s] or there is any other reason to suspect that the interpretation does not reflect the agency's fair and considered judgment on the matter in question. ${ }^{176}$

The Court then summarized the three steps that the agency had taken in reaching its interpretive result. ${ }^{177}$ The Court concluded its review of the FCC interpretation by accounting for the FCC's previous action, following a skeptical decision of the D.C. Circuit, to amend its regulation's "definition of dedicated transport-a type of network element - to include entrance facilities." " conclusion that entrance facilities are part of an incumbent LEC's network as "more than reasonable"179 and "perfectly sensible."180 At the end of its analysis, the Court came to its own conclusion that "[e]ntrance facilities, at least when used for the mutual exchange of traffic, seem to us to fall comfortably within the definition of interconnection." 181 For good measure, the Court added that "there is no danger that deferring to the Commission would effectively permit the agency, under the guise of interpreting a regulation, to create de facto a new regulation." 182

Having concluded that the substance of the agency interpretation was reasonable, the Court turned to whether the interpretation "reflect[ed] the agency's fair and considered judgment on the matter in question." "183 The Court stated that, "although the FCC concedes that it is advancing a novel interpretation of its longstanding interconnection regulations, novelty alone is not a reason to refuse deference." ${ }^{\prime 184}$ The Court emphasized that the agency had not changed its ultimate conclusion, but had simply revised the reasons supporting the conclusion. ${ }^{185}$ The Court also stated that the FCC's expertise and experience in addressing a complicated regulatory issue warranted judicial deference. ${ }^{186}$

\footnotetext{
176. Talk America, 131 S. Ct. at 2261 (2011) (quotation marks omitted) (citations omitted).

177. See id.

178. Id. at 2262 (citations omitted).

179. Id.

180. Id.

181. Id. at 2263 (citation omitted).

182. Id. (quotation marks omitted) (citation omitted)

183. Id. at 2261(quotation marks omitted) (citations omitted).

184. Id. at 2263.

185. See id. at 2264 ("The Commission then found another way to support that same conclusion."); see also id. at 2265 ("[T]he Triennial Review Remand Order reinstated the ultimate conclusion of the Triennial Review Order and changed only the analysis through which [it] reached that conclusion." (quotation marks omitted) (citation omitted)).

186. The Court stated in this regard that:

The parties and their amici dispute whether an incumbent LEC has any way of knowing
} 
Justice Scalia concurred in the Court's judgment. ${ }^{187} \mathrm{He}$ abjured the use of Auer deference, concluding that the FCC interpretation was "the fairest reading of the orders in question." have been clearer, but its meaning as written was sufficiently clear, without any need for deference. ${ }^{189}$ Justice Scalia then proceeded to present a strong criticism of Auer deference, despite the fact that "in the past [he] uncritically accepted that rule." ${ }^{, 190}$ He contended that the rule of deference conflicts with basic separation of powers principles by allowing the same government actor to make law, in the form of the regulation, and then apply that law by interpretation of the regulation. ${ }^{191}$ Justice Scalia argued that independent review is necessary for the application of law. ${ }^{192}$ He then stated his willingness to reconsider Auer deference in a proper case. ${ }^{193}$

The approach of the majority in Talk America is similar to the Court's approach in Coeur Alaska. In both cases, the Court purported to apply Auer deference. The Court's analysis, however, differs from proper Chevron deference. The Court gave "deference" only after it concluded that the agency had not changed its position. The Court focused its analysis far more on how convincing the agency's interpretation was, rather than on whether, as in Chevron analysis, the law being interpreted (here, the agency regulations) is sufficiently ambiguous to permit the agency interpretation. This less deferential approach is understandable given that the agency's position, defined in an amicus brief, ${ }^{194}$ would not have received Chevron deference if the

how a competitive LEC is using an entrance facility. This technical factual dispute simply underscores the appropriateness of deferring to the FCC. So long as the Commission is acting within the scope of its delegated authority and in accordance with prescribed procedures, it has greater expertise and stands in a better position than this Court to make the technical and policy judgments necessary to administer the complex regulatory program at issue here.

Id. at 2265 n. 7 .

187. Id. at 2265 (Scalia, J., concurring).

188. Id. at 2266 .

189. See id.

190. Id.

191. See id.

192. See id. ("[W]hen an agency promulgates an imprecise rule, it leaves to itself the implementation of that rule, and thus the initial determination of the rule's meaning. And though the adoption of a rule is an exercise of the executive rather than the legislative power, a properly adopted rule has fully the effect of law. It seems contrary to fundamental principles of separation of powers to permit the person who promulgates a law to interpret it as well.").

193. See id.

194. See supra note 174 and accompanying text. 
agency had been interpreting a statute. ${ }^{195}$ The Court's approach in Talk America was similar to its approach in Coeur Alaska and it applied Auer deference as though it were Skidmore review. In both cases, the Court itself actually made the substantive interpretation of ambiguous law, despite purporting to give Auer deference to the agency. ${ }^{196}$

\section{The Meadification of Auer Deference: Christopher v. SmithKline Beecham Corp.}

The Court's consideration of Auer deference took yet another turn in Christopher v. SmithKline Beecham Corp. ${ }^{197}$ This case concerned the legal status of drug detailers, which are employees who provide pharmaceutical information and promote prescription drugs to doctors. ${ }^{198}$ Pharmaceutical companies took the position that these workers were "outside salesm[e]n" under the Fair Labor Standards Act (FLSA) and were therefore not subject to that statute's requirements regarding timeand-a-half wages for overtime. ${ }^{199}$ The statute did not include a definition of an "outside salesman," but instead delegated authority to the Department of Labor (DOL) to define the term. ${ }^{200}$

Although the Court did not directly state that the regulations were ambiguous regarding the categorization of the detailers as "outside salesm[e]n," the inference of regulatory ambiguity follows because the Court felt it necessary to address the question "whether the DOL's interpretation of the regulations is owed deference under Auer $v$. Robbins, 519 U.S. 452 (1997).,"201

The DOL's position that the drug detailers were subject to the FLSA

195. Mead would not view the filing of an amicus brief as an agency's exercise of lawmaking power, assuming that Congress had delegated such power to the agency.

196. See supra notes $158-63,177-85$ and accompanying text.

197. 132 S. Ct. 2156 (2012).

198. See id. at 2163-64 ("Pharmaceutical companies promote their prescription drugs to physicians through a process called 'detailing,' whereby employees known as 'detailers' or 'pharmaceutical sales representatives' provide information to physicians about the company's products in hopes of persuading them to write prescriptions for the products in appropriate cases. The position of 'detailer' has existed in the pharmaceutical industry in substantially its current form since at least the 1950's, and in recent years the industry has employed more than 90,000 detailers nationwide." (citations omitted)).

199. See id. at 2164.

200. Id. at 2162 .

201. Id. at 2165 (citation omitted). As was discussed previously, a court has not been required by the Auer standard to consider first whether the regulation has a clear meaning regarding the legal question. See supra notes 84-89 and accompanying text. 
had been presented in a series of amicus briefs beginning in 2009. ${ }^{202}$ The Court responded to the request for Auer deference by identifying multiple circumstances under which such deference is not owed to the agency:

Although Auer ordinarily calls for deference to an agency's interpretation of its own ambiguous regulation, even when that interpretation is advanced in a legal brief, this general rule does not apply in all cases. Deference is undoubtedly inappropriate, for example, when the agency's interpretation is plainly erroneous or inconsistent with the regulation. And deference is likewise unwarranted when there is reason to suspect that the agency's interpretation does not reflect the agency's fair and considered judgment on the matter in question. This might occur when the agency's interpretation conflicts with a prior interpretation, or when it appears that the interpretation is nothing more than a convenient litigating position, or a post hoc rationalization advanced by an agency seeking to defend past agency action against attack. ${ }^{203}$

The Court concluded that, in this case, "there are strong reasons for withholding the deference that Auer generally requires." 204 The agency had changed its interpretation of the regulation in a way that resulted in " "unfair surprise" "205 as a result of the "impos[ition] [of] potentially massive liability on respondent for conduct that occurred well before that [new] interpretation was announced."206 The Court believed deference would undermine the APA requirement that an agency pursue notice and comment rule making before it changed its regulations. ${ }^{207}$ The Court therefore refused to accord Auer deference to the agency interpretation. ${ }^{208}$ Having rejected Auer deference, the Court immediately stated that:

202. See id. The Court restated its view that an agency interpretation of regulations included in an amicus brief may properly receive Auer deference. See id. at 2166 (citing Chase Bank USA, N.A. v. McCoy, 131 S. Ct. 871, 880 (2011)).

203. Id. at 2166 (citations omitted) (quotation marks omitted).

204. Id. at 2167.

205. Id.

206. Id.

207. See id. at 2168 .

208. See id. at 2168 ("[W]hatever the general merits of Auer deference, it is unwarranted here."). Justice Breyer seemed to agree in his dissent that the DOJ position did not warrant deference. See $i d$. at 2175 (Breyer, J., dissenting) ("In light of important, near-contemporaneous differences in the Justice Department's views as to the meaning of relevant Labor Department regulations, I also agree that we should not give the Solicitor General's current interpretive view any especially favorable weight." (citation omitted)). 
We instead accord the Department's interpretation a measure of deference proportional to the 'thoroughness evident in its consideration, the validity of its reasoning, its consistency with earlier and later pronouncements, and all those factors which give it power to persuade.' United States v. Mead Corp., 533 U.S. 218, 228 (2001) (quoting Skidmore v. Swift \& Co., 323 U.S. 134, 140 (1944)). ${ }^{209}$

There are two important dimensions to the Court's interpretive approach. First, the Court clearly confirms, if there was any doubt, that it understands Auer deference to be different than Skidmore review. SmithKline is accordingly in tension with Coeur Alaska and Talk America, both of which had applied Auer deference so that it was equivalent to Skidmore review. ${ }^{210}$ SmithKline is, however, consistent with Oregon, which took the traditional view that Auer deference is equivalent to Chevron deference. ${ }^{211}$

The second important aspect of the Court's analysis in SmithKline is that the Court effectively imposed a test to determine whether an agency interpretation of regulations ought to receive the preferred deferential standard. This test performs a function that is the same as the test for the application of Chevron deference defined by Mead. Moreover, the consequence of failing the test for the application of Auer deference is precisely the same as for failing the Mead test: the Court proceeds with Skidmore review. ${ }^{212}$

The Court then assessed the agency's interpretation and was wholly unconvinced by it, concluding that it was not "persuasive in its own right." 213 Because the agency was unpersuasive, the Court stated that it "must employ traditional tools of interpretation to determine whether petitioners are exempt outside salesmen." 214 It is notable that the Court understood review under the Skidmore standard as different than the Court reaching its own interpretive judgment. In this regard, the Court appears to have been tricked by the misleading nomenclature of Skidmore "deference." The Skidmore regime does not actually involve

209. Id. at 2168-69 (citations omitted).

210. See supra Parts III.B and III.C.

211. See supra Part III.A.

212. This analytic approach also has the effect of reinforcing the Court's traditional understanding of the equivalence of Chevron and Auer deference. See, e.g., supra note 137 and accompanying text. The Court had appeared in Coeur Alaska and Talk America to view Auer deference as weaker than Chevron deference. See supra note 196 and accompanying text.

213. SmithKline, 132 S. Ct. at 2170.

214. Id. 
deference by a court. ${ }^{215}$ That regime, instead, allows the agency the chance to convince the court of the persuasiveness of its position based on its experience and expertise. The ultimate interpretive judgment is, however, for the court, which independently evaluates the agency's persuasiveness and decides for itself the best interpretation of the regulation. ${ }^{216}$ Moreover, given how the SmithKline Court defined the test to determine whether Auer deference is applicable, ${ }^{217}$ it is unlikely there will be many cases in which the agency view persuades the court, because the court will have previously decided that the circumstances indicate that Skidmore review, rather than Auer deference, is warranted. The Court's analysis makes an agency's change in the interpretation of its ambiguous regulations ${ }^{218}$ doubly problematic for the agency. Such a change is a reason to deny Auer deference and a reason for reduced persuasive value under Skidmore. The result is that an agency is encouraged to amend the regulations in accordance with required rule making procedures, rather than change its interpretation of them.

The SmithKline Court then applied its own independent interpretive judgment and concluded that the drug detailers were exempt from the wage and hour requirements of the FLSA. ${ }^{219}$

\section{E. A Last Gasp for Auer Deference?: Decker v. Northwest Environmental Defense Center}

The Court returned to the question of Auer deference in the October 2012 Term. In Decker v. Northwest Environmental Defense Center, ${ }^{220}$ the Court considered a citizen suit in which the plaintiff claimed that logging companies in Oregon had violated the Clean Water Act by discharging pollution into "waters of the United States" without necessary permits. ${ }^{221}$ The relevant discharges had resulted from the use of culverts, pipes and other conveyances to transport storm runoff that

\footnotetext{
215. See supra note 82 and accompanying text.

216. See SmithKline, 132 S. Ct. at 2170.

217. See supra note 203 and accompanying text.

218. Recall that if the meaning of the regulation is clear, the agency is bound by the content of that law. See Vitarelli v. Seaton, 359 U.S. 535, 545 (1959). When a regulation is clear, the agency's only option to change the content of the law is by amending the regulation in compliance with statutory procedural requirements: An agency may not change a regulation by an interpretation. See Shalala v. Guernsey Mem'l Hosp., 514 U.S. 87, 100 (1995).

219. SmithKline, 132 S. Ct. at 2173.

220. 133 S. Ct. 1326 (2013).

221. Id. at 1330.
} 
contained eroded soil and materials from logging roads. ${ }^{222}$ The government nevertheless did not require a permit because its interpretation was that these discharges were not "associated with industrial activity." 223 The court of appeals had concluded that the regulation was unambiguous that the discharge was subject to the permit requirement. $^{224}$

The Supreme Court concluded first that the statute was ambiguous because the statutory term "industrial activity" has "multiple definitions" and the statute "provides no further detail as to its intended scope." 225 The Court then found the regulations to be ambiguous regarding whether "the regulation extends only to traditional industrial buildings such as factories and associated sites, as well as other relatively fixed facilities." 226 The Court found that "[t]he EPA's interpretation is a permissible one." 227 The Court viewed the EPA as reasonable in its view that discharges had to be permitted only when they "related in a direct way to operations 'at an industrial plant.",228 In upholding the permissibility of the agency's interpretation, the Court relied upon the Auer deference standard. ${ }^{229}$

The Court then concluded that the limits on Auer deference enumerated in SmithKline were not applicable:

There is another reason to accord Auer deference to the EPA's

222. Id. at $1330-31$.

223. See id. at 1330 .

224. Id. at 1333-34. The EPA took action after the court of appeals decision to amend its regulations to specify clearly that a permit was required for "only those logging operations that involve the four types of activity (rock crushing, gravel washing, log sorting, and log storage facilities) that are defined as point sources by the explicit terms of the Silvicultural Rule." Id. at 1333. The final version of this amended regulation was promulgated a few days before the Supreme Court heard oral argument in the case. $I d$. at 1332.

225. Id. at 1336.

226. Id. at 1337.

227. Id.

228. Id. (quotation marks omitted).

229. See id. ("It is well established that an agency's interpretation need not be the only possible reading of a regulation - or even the best one - to prevail. When an agency interprets its own regulation, the Court, as a general rule, defers to it unless that interpretation is plainly erroneous or inconsistent with the regulation." (citations omitted) (quotation marks omitted)). Justice Scalia maintained that the agency's interpretation was hardly the best. See id. at 1339 (Scalia, J., concurring in part and dissenting in part) ("The Court there gives effect to a reading of EPA's regulations that is not the most natural one, simply because EPA says that it believes the unnatural reading is right. It does this, moreover, even though the agency has vividly illustrated that it can write a rule saying precisely what it means - by doing just that while these cases were being briefed."). 
interpretation: there is no indication that its current view is a change from prior practice or a post hoc justification adopted in response to litigation. See Christopher v. SmithKline Beecham Corp., 132 S. Ct. 2156, 2166-2167 (2012). The opposite is the case. The agency has been consistent in its view that the types of discharges at issue here do not require NPDES permits. ${ }^{230}$

Despite having concluded that deference was appropriate because the agency interpretation was reasonable, the Court added its own additional reason for the agency interpretation: the agency's approach furthered the statute's goal of coordinating federal and local controls on storm water pollution. ${ }^{231}$ This additional rationale suggested, perhaps, the Court's discomfort with the permissibility of the agency's interpretation, especially given the sharp dissent of Justice Scalia.

The Decker Court accordingly viewed Auer deference as equivalent to Chevron deference, ${ }^{232}$ which starkly contrasts with Skidmore review. The Court applied its rule that an agency would not always receive Auer deference for its interpretation of a regulation. The Court continued to test whether Auer deference was appropriate. One reason why a court will not accord Auer deference to an interpretation is that the agency has changed its interpretation. ${ }^{233}$ Critically, however, the Decker Court clearly accepted the permissibility of applying a properly deferential standard, despite the sharply stated, continuing dismay of Justice Scalia, who again criticized the permissibility of deference to an agency interpretation of its regulations on separation of powers grounds. ${ }^{234}$ Justice Kennedy's opinion for the majority again responded to this foundational critique with silence. Chief Justice Roberts, joined by Justice Alito, did concur, however, and stated that Justice Scalia "raises

230. Id. at $1337-38$ (citations omitted).

231. See id. at 1338.

232. Justice Scalia agreed with this understanding of the effect of Auer deference. See id. at 1339-40 (Scalia, J., concurring in part and dissenting in part) ("The canonical formulation of Auer deference is that we will enforce an agency's interpretation of its own rules unless that interpretation is plainly erroneous or inconsistent with the regulation. But of course whenever the agency's interpretation of the regulation is different from the fairest reading, it is in that sense 'inconsistent' with the regulation. Obviously, that is not enough, or there would be nothing for Auer to do. In practice, Auer deference is Chevron deference applied to regulations rather than statutes. The agency's interpretation will be accepted if, though not the fairest reading of the regulation, it is a plausible reading - within the scope of the ambiguity that the regulation contains." (citations omitted) (quotation marks omitted)).

233. The Court was less consistent in the order of its analysis. In Decker, the Court applied the analysis of whether Auer deference is appropriate after the Court applied that standard of review. See id. at $1337-38$.

234. See id. at 1339-41 (Scalia, J., concurring in part and dissenting in part). 
serious questions about the principle set forth in [Seminole Rock and Auer]. It may be appropriate to reconsider that principle in an appropriate case. But this is not that case." 235

\section{F. Conclusion}

This group of five cases presents a Court that has become increasingly uncertain about Auer deference. The Court's uncertainty has several sources. Most importantly, the Court's decision in Mead narrowed the scope of application of Chevron deference. The Court appears quite uncomfortable giving an agency Chevron-like deference, when the agency interpretation would not meet the requirements for Chevron deference defined by Mead. Indeed, the Court faced exactly this problem in Coeur Alaska.

The Court's solution to this problem in Coeur Alaska was to treat Auer deference as equivalent to Skidmore review, rather than to Chevron deference. $^{236}$ This approach resolves the problem posed by Mead by simply treating Auer deference as equivalent to Skidmore review, which applies when Mead determines that Chevron deference is not applicable. The approach, however, conflicts with the long-standing understanding of Auer deference, which had been that Auer deference is equivalent to Chevron deference.

The Mead test for the application of Chevron deference also appears to have caused uncertainty for the Court about the proper nature of Auer deference. The effect of Mead analysis is that an agency must, in effect, win the application of proper Chevron deference by actually making law in the exercise of delegated lawmaking power. ${ }^{237}$ In three of the recent

235. Id. at 1338. Justice Breyer did not participate in the decision.

236. See supra Part III.B. The Court gave the same reduced effect to Auer deference in Talk America. See supra Part III.C.

237. See Stephenson \& Pogoriler, supra note 19, at 1464 (footnote omitted), who state that: In the statutory interpretation context, agencies have a choice: they can use notice-andcomment proceedings to promulgate their statutory interpretations as legislative rules, in which case they will presumptively receive Chevron deference, or they can opt to issue these interpretations informally as interpretive rules, in which case they will have to defend their interpretations under the less deferential Skidmore standard. But they have to select one or the other. This 'pay me now or pay me later' principle has gradually emerged as a crucial feature of the doctrine, one that allows courts to avoid direct regulation of agency choice of policymaking form while retaining some form of meaningful check - either ex ante procedural safeguards or ex post judicial scrutiny —on administrative decisions.

Cf. Stack, supra note 6, at 398-99 ("As reflected in the Supreme Court's decision in United States v. Mead Corp., statutory authority alone is not sufficient to warrant deference under Chevron; the 
quintet of cases, the Court viewed Auer deference as equivalent to Chevron deference. These three cases, Oregon, SmithKline, and Decker, followed the lead of Mead by establishing limits on the scope of application of proper Auer deference. Oregon held that an agency would not receive Auer deference when Congress, rather than the agency, was actually the source of the law being interpreted. SmithKline and Decker held that the deferential Auer standard applied to an agency's interpretation of regulations it had promulgated only when the interpretation had not changed and the interpretation was not a post-hoc rationalization. These cases thus build on Mead by establishing that there must be a test of applicability for a standard of review that, as with Chevron, is properly deferential to an agency.

It is important also to consider what these two limits tell us about the post-Mead Court's understanding of the nature of Auer deference. An agency's ability to change its interpretation has long been an important consideration when a court reviews an agency's legal interpretation. The Skidmore review standard discounts the persuasiveness of the agency's interpretation when that interpretation has changed. ${ }^{238}$ Chevron deference then altered the legal significance of an agency's change in position:

[C]hange is not invalidating, since the whole point of Chevron is to leave the discretion provided by the ambiguities of a statute with the implementing agency. An initial agency interpretation is not instantly carved in stone. On the contrary, the agency ... must consider varying interpretations and the wisdom of its policy on a continuing basis, for example, in response to changed factual circumstances, or a change in administrations. That is no doubt why in Chevron itself, this Court deferred to an agency interpretation that was a recent reversal of agency policy. $^{239}$

In short, as long as an agency's changed interpretation fits within the space created by the legal ambiguity, Chevron deference accepts the agency's changed interpretation as permissible.

The Court's decision post-Mead to reject the application of proper Auer deference when an agency changes its position shows that the Court

\footnotetext{
agency's reason-giving is a precondition to, and the object of, deference. In other words, the agency's reasoned analysis is the coin by which it pays for (and warrants) deference to its interpretation of the law." (footnotes omitted)).

238. See Skidmore v. Swift \& Co., 323 U.S. 134, 140 (1944).

239. Nat'l Cable \& Telecomms. Ass'n v. Brand X Internet Servs., 545 U.S. 967, 981-82 (2005) (citations omitted) (quotation marks omitted).
} 
is unwilling simply to accept an agency's movement within the space created by the ambiguity in its own regulation. ${ }^{240}$ This apparent willingness on the Court's part to grant proper deference to only a single permissible interpretation was motivated in SmithKline by the majority's concern that a regulated party would be unfairly surprised by a changed interpretation, especially one that "impose[d] potentially massive liability" on that party. ${ }^{241}$ Justice Scalia has advocated this concern most stridently by urging that the Court abandon Auer deference in his dissenting and separate opinions. ${ }^{242}$

Moreover, an agency's ability to change its interpretation of a regulation undercuts the value that rule making has in notifying regulated parties about the applicable legal standard. ${ }^{243}$ If an agency is able to change its interpretation and receive judicial deference, the agency is able to avoid the notice and comment rule making process and the interaction with regulated parties. ${ }^{244}$ An agency's change in its interpretation of its regulations also weakens to some degree the Accardi principle because such a change allows the agency to change the application of the rule, despite Accardi's mandate that an agency be bound by its rules. $^{245}$ In sum, the Court's first post-Mead limit on the application of Auer deference importantly eliminates a key characteristic of Chevron deference.

The second limit on the application of Auer deference is that the agency interpretation must not be a post-hoc rationalization by the agency. This limitation seems analogous to the long-standing limit on agency interpretations of statutes: such interpretations must pass muster substantively and must also result from a proper decisionmaking

240. The Court's view of the significance of an agency's change of position in the Auer deference context has not been consistent. In Long Island Health Care at Home v. Coke, 551 U.S. 158, 170-71 (2007) (citations omitted), the Court stated that: "[W]e concede that the Department may have interpreted these regulations differently at different times in their history. But as long as interpretive changes create no unfair surprise ... the change in interpretation alone presents no separate ground for disregarding the Department's present interpretation." Ensuring that there is no "unfair surprise" is very different than rejecting the otherwise applicable review standard based on a change in interpretation.

241. Christopher v. SmithKline Beecham Corp., 132 S. Ct. 2156, 2167 (2012).

242. See Decker v. Nw. Envtl. Def. Ctr., 133 S. Ct. 1326, 1339 (2013); Talk Am., Inc. v. Mich. Bell Tel. Co., 131 S. Ct. 2254, 2265-66 (2011).

243. See, e.g., SEC v. Chenery Corp., 332 U.S. 194, 202 (1947); Nat'l Petroleum Refiners Ass'n v. F.T.C., 482 F.2d 672, 681-84 (D.C. Cir. 1973).

244. See 5 U.S.C. $\$ 553$ (2012) (prescribing procedures for informal rule making).

245. The Accardi principle is discussed supra at notes $85-86$ and accompanying text. 
process. $^{246}$ In the statutory interpretation context, the Court has not seen this requirement as a limit on the scope of applicability of the standard for deferring to the agency's substantive interpretation. Rather, the Court has held that even if the agency's substantive interpretation is lawful, the interpretation remains subject to arbitrary or capricious review to ensure that the agency has considered the proper factors and provided a sufficient explanation of its interpretation. Ensuring a proper process of decisionmaking also seems appropriate in the context of the interpretation of a regulation.

Having considered the Court's new limits on the application of proper Auer deference, we turn to a final source of uncertainty about Auer deference in the post-Mead era. Justice Scalia has presented on two recent occasions the strong critique that Auer deference conflicts with core separation of powers principles: the branch that makes law should not have the power to interpret and apply that law as well. ${ }^{247}$ This critique holds that the judiciary must itself interpret agency regulations. Justice Scalia's long-delayed mission to abolish Auer deference, after having written the post-Chevron opinion that gives the name to this standard of deference, shows that the Court applied deference in this context without ever establishing any clear rationale for its use. The lack of theoretical support for Auer deference contrasts sharply with the articulation of administrative law theory to support Chevron deference.

Although the Court has so far retained Auer deference with a narrowed scope of applicability in the face of Justice Scalia's foundational critique, the Court recently curtailed its scope of application or applied the standard as though it were Skidmore review. Having now considered the past and present of Auer/Seminole Rock deference, we turn to a consideration of the future and the need for a theoretically defensible standard of review that accounts for both form and function in administrative law.

246. See Healy, supra note 1 , at $43,49-50$.

247. See supra note 242 . 


\section{THE FUTURE: A PROPERLY THEORIZED STANDARD OF REVIEW FOR AN AGENCY INTERPRETATION OF ITS OWN REGULATIONS}

\section{A. Define a Two-Step Standard for Reviewing an Agency's Interpretation of Its Regulation}

This section will present theoretical support for the adoption of a new rule of deference when a court reviews an agency's interpretation of its own regulations. From its initial articulation in Seminole Rock, the rule of deference to an agency's interpretation of its regulations has been muddled by the Court's immediate incantation that it would accept all but a "plainly erroneous" interpretation, ${ }^{248}$ without first requiring that the court exercise its role of determining the content of already-defined law. ${ }^{249}$ The result of this flawed order of analysis in Seminole Rock was that the Court purported to be deferring to an agency interpretation of law that was clearly compelled by the terms of the regulation. ${ }^{250}$ Even after Chevron defined its now-famous two-step order of analysis, the Court adhered to a one-step approach when reviewing regulations, beginning its analysis with its deferential standard. ${ }^{251}$

Defining a two-step order of analysis would make review of an agency's application of its regulations more like judicial review of an agency's interpretation of a statute. The change would also emphasize the significance of the status of a regulation as law, to which a court must defer under Chevron, and which binds an agency until the agency amends that law by conforming to the informal rule making process prescribed by $\S 553$ of the APA. ${ }^{252}$ Just as with a statute, if a regulation is clear in its requirements as determined by a court, that clear law binds the agency. A newly defined first step when a court reviews an agency's interpretation of its regulations would encourage attention to the method or methods for interpreting regulations. ${ }^{253}$

248. Bowles v. Seminole Rock \& Sand Co., 325 U.S. 410, 414 (1945).

249. The lack of this step-one inquiry may explain why there has not been a coherent body of law relating to the proper interpretation of regulations. See Stack, supra note 6, at 368 ("The dearth of doctrine addressing regulatory interpretation under Chevron can be partially explained by the well-established doctrine, attributed to Bowles v. Seminole Rock \& Sand Co. and Auer v. Robbins, that an agency's construction of its own regulation is controlling unless plainly erroneous or inconsistent with the regulation." (footnote omitted) (quotation marks omitted)).

250. See supra notes 41-43 and accompanying text.

251. See supra text following note 84 .

252. 5 U.S.C. $\$ 553$ (2012). Or, in very rare cases, the agency conforms with formal rule making requirements. See id. $\$ 556-557$.

253. Justice Scalia has, unsurprisingly, advocated a textualist approach to such interpretations. 
Justice Scalia, in his dissent in Decker, contends that a court should simply construe an agency's regulation based only on its text, neither according deference to the agency nor considering the advisability of the agency's interpretation. ${ }^{254}$ Because Justice Scalia has now concluded that proper Auer deference is not permissible given the insurmountable separation of powers concerns, he appears to have concluded that it does not matter whether the court-determined meaning is clear or the best reading of an ambiguous regulation. ${ }^{255}$

As discussed in the next section, this article advocates Skidmore review when a court interprets an ambiguous regulation. The approach presented in the next section locates the interpretive power in the court and thereby accounts for, inter alia, the separation of powers concern. The proposed approach, however, retains a role for the agency, which may seek to persuade the court that its interpretation should be adopted by the court as the best interpretation. Because the court wields interpretive authority at both of the proposed steps of review, dividing review into two steps has far less significance than in a case in which proper Chevron deference applies. ${ }^{256}$ Notwithstanding this diminished

See Decker v. Nw. Envtl. Def. Ctr., 133 S. Ct. 1326, 1342 (2013) (Scalia, J., concurring in part and dissenting in part) ("I would therefore resolve these cases by using the familiar tools of textual interpretation to decide."). Justice Scalia specifically rejected an interpretative approach that would account for the agency's intent. See id. at 1340 ("There is true of regulations what is true of statutes. As Justice Holmes put it: '[w]e do not inquire what the legislature meant; we ask only what the statute means.' Whether governing rules are made by the national legislature or an administrative agency, we are bound by what they say, not by the unexpressed intention of those who made them." (alteration in original) (citation omitted) (quoting Oliver Wendell Holmes, The Theory of Legal Interpretation, 12 HARV. L. REV. 417, 419 (1899))).

Professor Stack has presented a forceful argument in favor of a purposivist approach to interpretation, relying on how notice and comment rule making defines the content of law. See generally Stack, supra note 6. Notwithstanding the strong views stated by Justice Scalia, the Court has on at least one occasion suggested that, when interpreting a regulation, the agency's intent is properly considered. See Gardebring v. Jenkins, 485 U.S. 415, 430 (1988); cf. Manning, supra note 6, at 690 ("In a Skidmore regime, if the Court looked to statements of basis and purpose for evidence of the linguistic and cultural environment in which a regulation was adopted, agencies would presumably respond by tailoring such statements to that application. If so, the resulting explanations of agency regulations would simultaneously enhance the clarity of agency decisionmaking and the accuracy of judicial review." (footnotes omitted)).

254. See Decker, 133 S. Ct. at 1342 (Scalia, J., concurring in part and dissenting in part).

255. Brand $X$, of course, makes this distinction important when an agency has interpreted a statute but has not acted in the exercise of delegated lawmaking power. See Nat'l Cable \& Telecomms. Ass'n v. Brand X Internet Servs., 545 U.S. 967, 983 (2005). In that context, an agency could change the court's interpretation if the statute were ambiguous and the agency exercised its delegated lawmaking power and adopted an alternate interpretation that was not clearly barred by the statute (under step one of the Chevron analysis). See id. at 982-83, 985.

256. It is very important to pursue the first step of Chevron analysis at the outset of a court's review of an agency's interpretation of a statute. When an agency interprets a statute and the statute 
importance of the two-step approach, the approach remains helpful in administrative law because substantial legal significance attaches to whether applicable law is clear or ambiguous.

Adopting a two-step approach would be a notable, although principally cosmetic, change. The question of true controversy is the standard for judicial review of an agency's interpretation of an ambiguous regulation. This is the question that we will now address.

\section{B. Apply Skidmore Review to an Agency Interpretation of an Ambiguous Regulation}

The Supreme Court's decisions regarding Auer deference in the years since Mead show a Court that is unsure about the content of a proper standard, as well as how such a standard fits into the body of administrative law. The Court should now abandon the line of cases applying Auer deference and christen a new review standard when an agency interprets an ambiguous regulation. This new review standard would be equivalent to Skidmore review and would permit the agency to seek to convince the court that its interpretation should be adopted - that its interpretation is the best, rather than merely a permissible interpretation. ${ }^{257}$ Interpretive authority would, however, be definitively and critically located in the court. If this proposed standard of review were adopted, the new standard would apply in every case in which an agency has interpreted its own ambiguous regulations. ${ }^{258}$ This part of the article will present the multiple compelling arguments supporting this new standard of review.

is clear in barring the agency's interpretation, there is no need to engage in the Mead analysis to determine whether Chevron deference or Skidmore review applies. See Healy, supra note 1, at 3942. Moreover, if the statute is clear, then the agency does not have the authority under Brand $X$ to adopt its preferred interpretation through an exercise of delegated lawmaking power. See Brand X, 545 U.S. at $982-83$.

257. This is the same standard advocated by Professor Manning. See Manning, supra note 6, at 681 ("[T] he Court should modify Seminole Rock by embracing the approach of Skidmore v. Swift \& Co., which adopts a standard of review that accounts for agency expertise and experience when Congress has not delegated interpretive lawmaking authority under statutes. In that context, the Court has explained, an agency's interpretation does not bind a reviewing court." (footnotes omitted)).

258. Professors Stephenson and Pogoriler suggest other limitations on the applicability of Auer deference. Stephenson \& Pogoriler, supra note 19, at 1493-94. 


\section{Separation of Powers}

The constitutional separation of powers strongly supports a standard of review that requires the court itself to interpret the regulations promulgated by the agency. As Montesquieu long-ago argued ${ }^{259}$ and as Justice Scalia much more recently opined, ${ }^{260}$ the making of law must be separated from the application of law. ${ }^{261}$ The lawmaker and the law applier must not be one and the same. A regulation, of course, constitutes the making of law, while the interpretation of that law is an application of it. An independent actor, here a court, must have authority to review the application of agency-made law independently. ${ }^{262}$ Chevron/Auer deference does not permit that independent substantive review, ${ }^{263}$ while Skidmore review does. ${ }^{264}$ The Skidmore-review regime

259. See Montesquieu, SpiRit of the Laws bk. 11, ch. 6, 151-52 (O. Piest ed., T. Nugent trans. 1949), quoted in Decker v. Nw. Envtl. Def. Ctr., 133 S. Ct. 1326, 1341 (2013) (Scalia, J., concurring in part and dissenting in part) ("When the legislative and executive powers are united in the same person . . . there can be no liberty; because apprehensions may arise, lest the same monarch or senate should enact tyrannical laws, to execute them in a tyrannical manner.").

260. See Decker, 133 S. Ct. at 1341 (Scalia, J., concurring in part and dissenting in part) ("[T]he power to prescribe is augmented by the power to interpret; and the incentive is to speak vaguely and broadly, so as to retain a 'flexibility' that will enable 'clarification' with retroactive effect."); see also id. ("Auer is not a logical corollary to Chevron but a dangerous permission slip for the arrogation of power." (citation omitted)). Justice Scalia explained that Chevron deference does not give rise to the problem of Auer deference. See id. ("Congress cannot enlarge its own power through Chevron-whatever it leaves vague in the statute will be worked out by someone else. Chevron represents a presumption about who, as between the Executive and the Judiciary, that someone else will be. (The Executive, by the way-the competing political branch-is the less congenial repository of the power as far as Congress is concerned.) So Congress's incentive is to speak as clearly as possible on the matters it regards as important.").

261. See Manning, supra note 6, at 646-47 (discussing John Locke's strong argument that lawmaking had to be separated from law execution). Professor Manning's article presented the early, cogent case that Auer deference conflicts with the separation of powers. This case is more recently presented in Aneil Kovvali, Note, Seminole Rock and the Separation of Powers, 36 HARV. J.L. \& PUB. POL'Y 849 (2013).

262. See Stephenson \& Pogoriler, supra note 19, at 1460 ("[A] crucial difference between Chevron and Seminole Rock is that the former preserves a separation of legislative and interpretive power, whereas the latter allows these powers to be combined in a single entity. Even though Chevron involves a shift of interpretive power from the judiciary to an agency, the agency has the power to construe a text that was enacted by Congress. By contrast, Seminole Rock allows the agency to act as the primary interpreter of regulations that the agency itself promulgated." (footnote omitted)); See Stack, supra note 6, at 410 ("When a court defers to an agency's construction of its own regulation under Seminole Rock, it permits the agency to consolidate lawmaking and lawinterpreting functions. At a practical level, the doctrine creates incentives for the agency to issue broad and vague regulations and to specify their meaning later, subject only to plainly erroneous review, undermining rule-of-law values of fair notice." (footnotes omitted)).

263. See Manning, supra note 6, at 631 ("By permitting agencies both to write regulations and to construe them authoritatively, Seminole Rock effectively unifies lawmaking and law-exposition-a combination of powers decisively rejected by our constitutional structure."). 
does permit a court to account for agency experience and expertise by allowing the agency to explain and advocate for its interpretation. The court may account for the agency position to the extent that position is persuasive. The court will not, however, be bound by the agency, and will, instead, make its own substantive decision.

One famous analogy for understanding separation of powers was employed by the seventeenth century English writer, James Harrington. ${ }^{265}$ Harrington wrote that, when considering the sharing of a cake between parties, the person who divides the cake must not be the person who chooses the desired piece of cake if there is to be a fair sharing. ${ }^{266}$ The dividing of the cake analogy is important, because abandoning Auer deference forecloses an agency from being able to make law (divide the cake) in a way that the agency itself can later apply unfairly (distributing the pieces). ${ }^{267}$

Although not directly articulated by the Court, this concern might have animated the Court's decision in SmithKline. ${ }^{268}$ There, the Court declined to accord proper deference to the agency's interpretation because that interpretation had changed. This approach, which substantially reduces an agency's opportunity to surprise unfairly a regulated party by a changed interpretation of an ambiguous regulation, ${ }^{269}$ does not, however, sufficiently limit the agency's law application power in the face of an ambiguous law the agency itself has made. The regulation at issue in SmithKline was sufficiently ambiguous

264. See id. at 617 ("[T]he Court should replace Seminole Rock with a standard that imposes an independent judicial check on the agency's determination of regulatory meaning."); id. at 683 (“[I]f a court is not bound by an agency's interpretation of its own regulations, but must independently determine their meaning, then the constitutional fail-safe of having multiple actors performs its vital function.").

265. JAmes Harrington, The COMmonwealth of OCEANA (1656), reprinted in CAMBridge TeXts in The History of Political Thought 22, 24 (James G. Pocock ed., 1992).

266. See id. at 24 ("[I]f she that divided must have chosen also, it had been little worse for the other, in case she had not divided at all, but kept the whole cake unto herself, in regard that being to choose too, she divided accordingly.").

267. Harrington argues accordingly that the power to make law needs to be independent of the power to apply law. See id.

268. 132 S. Ct. 2156,2167 (2012).

269. An agency's changed interpretation of a statute does not give rise to the same concern about unfair surprise when Chevron deference applies under the Mead analysis. A change in the interpretation of a statute that follows rule making would provide notice to affected parties and would typically apply only prospectively. A change in the interpretation of a statute that followed a formal adjudication would be determined only after on-the-record procedures that ensured an adequate hearing that would allow for the consideration of the impact of a changed interpretation on a party to the adjudication. Moreover, the law being interpreted (the statute) would not have been written by the body deciding how to apply the law. 
to permit a conclusion that a large class of workers either was or was not subject to a statute that imposed a significant financial burden. If a regulation has that degree of ambiguity, then the agency should not have the power to choose the substantive interpretation, regardless of whether that interpretation is the agency's initial interpretation of the regulation or a subsequent changed interpretation. ${ }^{270}$ The agency's application of the ambiguous law conflicts with the separation of powers, regardless of whether that application is a changed or a consistent interpretation.

Justice Scalia, it should be recognized, has been strongly critical of the Skidmore standard for reviewing agency interpretations of law. One of the several matters that he bemoaned in his impassioned dissent in Mead was the majority's "breathing new life into the anachronism of Skidmore." $\mathrm{He}$ opined that "the rule of Skidmore deference is an empty truism and a trifling statement of the obvious: A judge should take into account the well-considered views of expert observers." ${ }^{272} \mathrm{He}$ also viewed the use of the standard as "a recipe for uncertainty, unpredictability, and endless litigation. To condemn a vast body of agency action to that regime... is irresponsible."273 In short, Justice Scalia views Skidmore review as nothing more than "that test most beloved by a court unwilling to be held to rules (and most feared by

270. See Stephenson \& Pogoriler, supra note 19, at 1453 (“[B]road judicial deference to an agency's interpretation of its own regulations may enable an agency to enact binding rules without subjecting itself either to meaningful procedural safeguards or to rigorous judicial scrutiny."). These authors described the contrasting incentives that Chevron-style deference creates for the bodies writing the law:

Congress knows (or should know) that when it leaves gaps, conflicts, or ambiguities in a statute, those ambiguities will be resolved by some other entity-either an administrative agency (under Chevron) or a court (if no agency administers the statute, or if Chevron does not apply). This gives Congress an incentive to write clearer statutes, lest another institution - perhaps a political rival - acquire control over the statute's meaning. This does not mean that Congress will always write statutes as clearly as possible: specificity must be weighed against other values, which is why Congress often delegates authority in the first place. But at least this consideration imposes a countervailing constraint. By contrast, under Seminole Rock, an administrative agency that writes vague regulations knows that it will be able to control their subsequent interpretation. Regulatory ambiguity, unlike statutory ambiguity, does not entail an implicit delegation to another institution, which makes such ambiguity relatively more attractive. This, in turn, leads both to regulatory unpredictability and concerns about arbitrariness.

Id. at 1461 (footnotes omitted); see also Manning, supra note 6, at 662 ("[T] interpretation under Seminole Rock reduces the efficacy of notice-and-comment rule making. In particular, it permits the agency to promulgate imprecise or vague rules and to settle upon or reveal their actual meaning only when the agency implements its rule through adjudication.").

271. United States v. Mead Corp., 533 U.S. 218, 250 (Scalia, J., dissenting).

272. Id.

273. Id. 
litigants who want to know what to expect): th' ol' 'totality of the circumstances' test.",274

Justice Scalia's condemnation of this review regime does not address the core of its significance, which is that the court itself has the authority to construe the legal source. Assuming that the court does properly exercise this interpretive authority-an assumption that Justice Scalia rejects in the Mead context but now accepts in the Auer context - the court ought to account for the expert views of the agency as the court comes to its own conclusion about the proper interpretation. Viewed in this light, Skidmore review is not a totality of the circumstances test, it is rather a proper accounting of the agency's experience and expertise by the judiciary. ${ }^{275}$

Redefining the standard of review to preclude proper deference is also consistent with the Court's long-standing view that Congress has the authority to define standards of review (and deference) when an agency action is challenged in court. ${ }^{276}$ Indeed, in its two most important modern standard of review decisions, Chevron and Mead, the Court has grounded its decision in the inferred intent of Congress. Chevron inferred that Congress intended that courts would defer to an agency's interpretation of an ambiguous statute, regardless of whether the ambiguity was intended or the result of inadvertence. ${ }^{277} \mathrm{Mead}$ thereafter limited the scope of application of Chevron deference, because the Court inferred that Congress intended for courts to defer to an agency's interpretation of a statute only when the agency had acted to make law pursuant to a congressional delegation of lawmaking power. ${ }^{278}$

Courts have long interpreted statutes to avoid a constitutional question unless compelled by clear language or intent. ${ }^{279}$ The Court has applied this rule to limit the scope of authority that an ambiguous statute

274. Id. at 241 .

275. See Manning, supra note 6, at 681 (“[A]n agency's interpretation of its own regulations, if not binding upon a reviewing court, retains value as a tool of construction. Congress's decision to commit lawmaking power to agencies vests substantial regulatory authority in specialized bodies with knowledge, expertise, and experience that generalist courts lack. Agencies may therefore have insights into regulatory history, context, or purpose that may not be readily apparent to even the most seasoned federal judge.").

276. See, e.g., Mead, 533 U.S. at 221; Healy, supra note 1, at 21.

277. See Chevron, U.S.A., Inc. v. Natural Res. Def. Council, Inc., 467 U.S. 837, 843-44 (1984) (quoted supra note 110).

278. See Mead, 533 U.S. at 226-27.

279. See, e.g., Nat'l Labor Relations Bd. v. Catholic Bishop of Chicago, 440 U.S. 490, 505-07 (1979). 
may otherwise have delegated to an administrative agency. ${ }^{280}$ Because delegating the power to interpret a regulation and then applying it against a regulated party raises such a fundamental separation of powers concern, a court should hold that Congress has not intended to delegate such power to an agency (in the absence of clear intent or text). ${ }^{281}$ In short, inferring legislative intent, as the Court has notably done when determining the proper standard of review, would confirm the conclusion that a deferential, Chevron-like review standard has no applicability to a court's review of an agency's interpretation of its own ambiguous regulation.

There is, to be sure, one administrative context in which recent Supreme Court precedent creates a tension with the position that a court must exercise interpretive authority when reviewing an agency interpretation of a regulation. Should a court properly defer when an ambiguous regulation is interpreted by an agency in a formal adjudication? ? $^{282}$ When an agency interprets a statute in a formal adjudication, the Mead analysis would indicate that Chevron deference applies, provided that Congress had delegated lawmaking power to the agency. ${ }^{283}$ When an agency is interpreting its own regulations in a formal adjudication, the agency is making law by applying the same law that the agency has previously defined. The fact that the application of the law occurs in a proceeding that provides greater procedural protections for the affected party does not change the fact that the agency is engaged in the application of law that the agency has made. Only Skidmore review should properly apply in this case because the separation of powers concerns about an agency applying agency-made law trump deference to an agency making law pursuant to a congressional delegation. ${ }^{284}$ Nevertheless, a court may, when reviewing

280. See, e.g., Solid Waste Agency of N. Cook Cnty. v. U.S. Army Corps of Eng'rs, 531 U.S. 159, 172-73 (2001) ("This requirement stems from our prudential desire not to needlessly reach constitutional issues and our assumption that Congress does not casually authorize administrative agencies to interpret a statute to push the limit of congressional authority.").

281. Cf. Decker v. Nw. Envtl. Def. Ctr., 133 S. Ct. 1326, 1341 (2013) (Scalia, J. concurring in part and dissenting in part) ("While the implication of an agency power to clarify the statute is reasonable enough, there is surely no congressional implication that the agency can resolve ambiguities in its own regulations. For that would violate a fundamental principle of separation of powers - that the power to write a law and the power to interpret it cannot rest in the same hands.").

282. Professors Stephenson and Pogoriler present the argument that such proper deference is appropriate in this context. See Stephenson \& Pogoriler, supra note 19, at 1486.

283. Mead, 533 U.S. at 230-31.

284. There is tension regarding the inferred intent of Congress relating to the deference, if any, owed to an agency: proper deference when a statute is interpreted in a formal adjudication, while 
an interpretation of regulations in a formal adjudication, conclude that the record presented by the agency has great persuasive value that supports the interpretation advocated by the agency. ${ }^{285}$ The court, however, will properly retain the power to decide how the law defined in the regulation should be applied.

\section{The APA}

In addition to this strong constitutional argument for abandoning traditional Auer deference, there is a strong statutory argument for an independent interpretive role for courts in this context. It is surprising that the Supreme Court has generally ignored the terms of the APA while shaping the rules of deference to administrative agencies ${ }^{286}$ despite that statute's significance for the structure of administrative law. ${ }^{287}$ Moreover, the Court has broadly declared that Congress has the authority to define the degree of deference to agency determinations. ${ }^{288}$ Indeed, the Court has engaged in the complex imputation of intent to Congress as it has developed the modern law of deference to agencies. ${ }^{289}$ The Court may have benefitted from directly considering the requirements of the APA when shaping the law of deference to agency interpretations of regulations.

Most importantly, the APA imposes significant procedural requirements on both formal ${ }^{290}$ and informal $^{291}$ rule making. The

Skidmore review is applied when the agency interprets a regulation in the formal adjudication. The tension is resolved, however, because a serious constitutional problem is presented when a court properly defers to an agency's interpretation of its own regulation.

285. Cf. Manning, supra note 6, at 686 ("[A]gencies may possess special experience and expertise that can assist a reviewing court in reaching its own conclusions about meaning." (footnote omitted)).

286. See supra note 75 and accompanying text; $c f$. Manning, supra note 6, at 636 ("[C]ourts have not treated the open-ended judicial review provisions of the APA and analogous statutes as firm expressions of legislative direction. Rather, the courts often appear to draw upon their own sensibilities in giving content to such provisions.").

287. See Bowen v. Georgetown Univ. Hosp., 488 U.S. 204, 216 (Scalia, J., concurring) ("I write separately because I find it incomplete to discuss general principles of administrative law without reference to the basic structural legislation which is the embodiment of those principles, the Administrative Procedure Act ...."); see also Strauss, "Deference" Is Too Confusing, supra note 76, at 1149 ("Agencies must be subject to judicial controls that reach into their assessment of factual and law-applying issues, that is, not to displace their responsibilities, but to assure their responsible, rational exercise. In 1946, the Administrative Procedure Act (APA) would embody this change.").

288. See Mead, 533 U.S. at 221.

289. See, e.g., supra notes 276-78 and accompanying text.

290. 5 U.S.C. $§ 556-557$ (2012); see also § 553(c) (defining when formal rule making requirements apply). 
rejection of Auer deference and adoption of Skidmore review would prevent an agency from interpreting its regulations, rather than amending its regulations in compliance with APA procedural requirements, and receiving judicial acceptance of the interpretation absent an actual conflict with the content of the regulations. ${ }^{292}$ The proposed approach would encourage agencies to define regulations as clearly as possible to avoid leaving the interpretive question to a reviewing court that will consider, but will not be bound by, the agency's interpretation. ${ }^{293}$ Such an approach would be analogous to the rule of reduced deference when an agency interprets a statute by issuing an interpretive rule without complying with the procedural requirements for legislative rules imposed by $\S 553 .^{294}$

This statutory rationale reinforces the separation of powers concern, which is greatest when the agency's regulations provide broad discretion to the agency regarding the application of the regulations. Justice Scalia, when he condemned the Court's decision in Mead, argued that one consequence of the decision would be that agencies would be encouraged to regulate in broad terms so that they could then rely upon Auer

\section{Id. § 553.}

292. See Stephenson \& Pogoriler, supra note 19, at 1461 ("Seminole Rock could enable agencies to adopt legally binding norms without either the ex ante constraint of meaningful procedural safeguards or the ex post check of rigorous judicial review."); $i d$. at 1467 ("“A] serious concern about unqualified Seminole Rock deference is that, when coupled with the interpretive rule exemption from notice-and-comment procedures, agencies can evade the 'pay me now or pay me later' structure of the doctrine by promulgating placeholder legislative rules that nominally go through notice and comment, but do not resolve key questions; the agency does the actual policymaking work by issuing interpretive rules that purport to interpret the placeholder rule, and by claiming both Seminole Rock deference and an exemption from notice and comment for these interpretive pronouncements.").

293. See Manning, supra note 6, at 655 ("The right of self-interpretation under Seminole Rock removes an important affirmative reason for the agency to express itself clearly; since the agency can say what its own regulations mean (unless the agency's view is plainly erroneous), the agency bears little, if any, risk of its own opacity or imprecision."); id. at 617 (Judicial deference to an agency's reasonable interpretation of its regulations "makes it that much less likely that an agency will give clear notice of its policies either to those who participate in the rule making process prescribed by the Administrative Procedure Act (APA) or to the regulated public."). Professor Manning also described additional benefits of a legal regime that incentivizes clearer rule making by agencies. See $i d$. at 680 ("[B]y encouraging agencies to write more straightforward and less malleable regulations, abandonment of Seminole Rock deference would help to give agencies some insulation from the influence of concentrated interest groups working through their favorite legislators or committees."); $i d$. ("Regulatory opacity, quite simply, makes it harder for the public to monitor agency decisionmaking, and leaves the agency more vulnerable to the influence of relatively narrow interest groups. As a doctrine designed to promote the political accountability of administrative decisionmaking, Seminole Rock is, at best, a mixed bag.").

294. See United States v. Mead Corp., 533 U.S. 218, 232 (2001) ("[I]nterpretive rules ... enjoy no Chevron status as a class."); Shalala v. Guernsey Mem'l Hosp., 514 U.S. 87, 99 (1995). 
deference and avoid the less deferential review of the agency's interpretation of a statute that might result from Mead analysis. ${ }^{295}$ Abandoning Auer deference eliminates any such agency incentive: Under the proposed review standard, a broadly written regulation would not augment agency discretion, but would instead transfer interpretive authority to the courts, which would have the power to interpret the agency's ambiguous regulation. ${ }^{296}$

\section{A More Consistent Regime of Deference}

The rejection of Auer deference would also have the practical advantage of identifying a more consistent regime of deference rules. The review of agency interpretations of regulations has always been subject to the expected requirement that an interpretation must not conflict with the regulations. ${ }^{297}$ Such a conflicting interpretation would have the effect of amending the regulation and would be permitted only if the regulation were itself amended through notice and comment rule making. The regulation itself thus had to be ambiguous with regard to the agency's interpretation in order to be subject to deferential review. This long-standing analysis is analogous to step one of the Chevron analysis, which inquires whether the statute itself bars the agency interpretation. This traditional limit on the interpretation of regulations would remain and be emphasized by the new first step of review of an agency's interpretation of regulations. ${ }^{298}$ The new rule of deference will apply only when the regulation is ambiguous with regard to the issue being decided by the agency.

The application of Skidmore review to ambiguous regulations fits with the result of the Mead analysis. Chevron deference is not typically owed when an agency adjudicates informally, a principal context for the application of regulations, many of which will be ambiguous as to the matter being determined. Mead views formal adjudication as the making of law, for which Chevron deference is appropriate. ${ }^{299}$ It is notable that Justice Scalia roundly criticized the Mead decision and the limitations

\footnotetext{
295. Mead, 533 U.S. at 246 (Scalia, J., dissenting).

296. See Manning, supra note 6, at 647 ("[S]eparation of lawmaking from law-exposition also limits arbitrary government by providing legislators an incentive to enact rules that impose clear and definite limits upon governmental authority, rather than adopting vague and discretionary grants of power." (footnote omitted)).

297. See Accardi, discussed supra at notes 85-86 and accompanying text.

298. See supra Part IV.A.

299. See Mead, 533 U.S. at 230-31.
} 
that it established for Chevron deference. ${ }^{300}$ In the Auer context, however, Justice Scalia has found his way to a similar limitation in the context of agency interpretations of regulations, this time by way of separation of powers. ${ }^{301}$ The resulting standard of review appears quite similar. Agency interpretations of regulations will most typically occur in an informal adjudication. It seems odd to conclude, under the Mead analysis, that Chevron deference is not generally owed in this broad range of cases and then, nevertheless, apply that same level of deference under the Auer rubric, when an agency is applying a regulation in the informal adjudication. ${ }^{302}$ The Court seemed to recognize this oddity when it decided Coeur Alaska and treated Auer deference as the equivalent of Skidmore review after having concluded that the agency's interpretation was not owed Chevron deference. ${ }^{303}$

Abandoning Auer deference will also ensure that every interpretive rule will be subject to the same Skidmore review standard. An agency may issue an interpretive rule to interpret either a statute or a regulation. The APA provides that an interpretive rule may be issued without complying with the APA procedural requirements for rule making. ${ }^{304}$ Mead confirmed that an agency would not receive Chevron deference for an interpretive rule that interpreted a statute. ${ }^{305}$ Chevron deference does not apply because the agency does not exercise delegated lawmaking power when it issues an interpretive rule. If, however, an agency were to issue an interpretive rule that interprets an ambiguous regulation, Auer deference would apply unless one of the Court's newly defined limits applied.

A deference regime that permits this inconsistent treatment of interpretive rules is quite problematic. Reshaping the review standard to remove proper deference for an agency interpretation of a regulation will eliminate the inconsistency and foreclose an agency's ability to receive proper Chevron-like deference when an agency simply announces its

300. Id. at 239 (Scalia, J., dissenting)

301. See Decker v. Nw. Envtl. Def. Ctr., 133 S. Ct. 1326, 1341 (2013) (Scalia, J. concurring in part and dissenting in part).

302. See Stack, supra note 6, at 411 (presenting a "proposal" that "corrects the incentives created by current doctrine, which generally denies Chevron deference to informal agency interpretations, such as those in agency litigation briefs, but grants deference under Seminole Rock to agency interpretations in briefs" (footnote omitted)).

303. Coeur Alaska, Inc. v. Se. Alaska Conservation Council, 557 U.S. 261, 283-84 (2009).

304. See 5 U.S.C. $\$ 553(\mathrm{~b})(3)(\mathrm{A})(2012)$.

305. See United States v. Mead Corp., 533 U.S. 218, 232 (2001); see also Shalala v. Guernsey Mem'1 Hosp., 514 U.S. 87, 99 (1995). 
interpretation of an ambiguous regulation.

\section{A Proper Consideration of the Source of Law}

The proposed standard of review for an agency's interpretation of its own regulations also properly accounts for the source of law. We have discussed the central significance of source of law to the rules of deference for judicial review of agency legal interpretations. ${ }^{306}$ Under Mead, proper Chevron deference is owed when the agency is the source of law, while Skidmore review applies when Congress is the source of the law. The fact that the agency is the source of law in the context of an interpretation of its own regulations pulls in different directions. The Mead analysis resulted in a strong rule of deference when the agency, rather than Congress, is the source of the law. That deference followed from the fact that, by enacting a statute ambiguous with regard to the legal issue resolved by the agency, Congress intended for the agency to have delegated authority to interpret the law. Accordingly, when an agency exercises delegated lawmaking authority, a court must defer to that agency-made law, rather than substitute its own view of a preferred interpretation. The Montesquieu separation of powers principles, as we have seen, weigh in favor of barring agency law-applying power, when the agency has also made the law. ${ }^{307}$ This is because the agency, when interpreting its own regulations, is engaged in a second order of lawmaking - it is applying the law that the agency itself has made and there is a need for independent review.

\section{Consistency with Basic Administrative Law Principles}

Allowing independent judicial review in this context, subject of course to the agency's ability to persuade but not to control, does not undercut the basic regime of administrative law. If a court were to be unpersuaded by an agency and interpret a regulation in a way that conflicted with the agency's interpretation, the agency would continue to have retained lawmaking authority to alter the legal rule adopted by the court. $^{308}$ If statutory ambiguity permits the agency's preferred, but

\footnotetext{
306. See supra notes 132-33 and accompanying text.

307. See supra notes $259-67$ and accompanying text.

308. Justice Scalia made this point in his opinion in Decker. He wrote:

It is true enough that Auer deference has the same beneficial pragmatic effect as Chevron deference: The country need not endure the uncertainty produced by divergent views of
} 
rejected, interpretation, the agency would retain the power to amend its regulations by employing the necessary procedures under $\S 553 .{ }^{309}$ The amended regulation, containing the preferred agency position, would then receive Chevron deference when reviewed in court and its substance would be accepted by a court, unless that substance were barred by the statute. In that case of a conflict with the statute, Congress would itself have defined the applicable legal rule. This ability of the agency to change the interpretation of the regulation would be analogous to the agency's ability, recognized in Brand $X$, to change a court's interpretation of an ambiguous statute, by exercising its delegated lawmaking power. ${ }^{310}$ Such a revised agency regulation incorporating its preferred interpretation would, of course, constitute the agency's making of law, informed by notice and comment, rather than the agency interpretation of the law defined in regulations that the agency itself also made.

This proposed standard of review would also result in the same standard of review for an agency's interpretation of its regulations as for an agency's interpretation of a statute when the agency has not acted in the exercise of delegated lawmaking power. An interpretive rule would then be reviewed under the same standard, regardless of whether that

numerous district courts and courts of appeals as to what is the fairest reading of the regulation, until a definitive answer is finally provided, years later, by this Court. The agency's view can be relied upon, unless it is, so to speak, beyond the pale. But the duration of the uncertainty produced by a vague regulation need not be as long as the uncertainty produced by a vague statute. For as soon as an interpretation uncongenial to the agency is pronounced by a district court, the agency can begin the process of amending the regulation to make its meaning entirely clear. The circumstances of this case demonstrate the point. While these cases were being briefed before us, EPA issued a rule designed to respond to the Court of Appeals judgment we are reviewing. It did so (by the standards of such things) relatively quickly: The decision below was handed down in May 2011, and in December 2012 the EPA published an amended rule setting forth in unmistakable terms the position it argues here ....

Decker v. Nw. Envtl. Def. Ctr., 133 S. Ct. 1326, 1341-42 (2013) (Scalia, J., concurring in part and dissenting in part) (citation omitted).

309. 5 U.S.C. $§ 553$ (2012); cf. Stack, supra note 6, at 415 ("If an agency (or a president) seeks to change policy that would be inconsistent with the prior rule and its statement, the agency has the capacity to do so by conducting a new rulemaking proceeding. To be sure, a notice-and-comment rulemaking can consume a great deal of agency resources. But it still requires the coordination of fewer parties with disparate interest than does legislation, and can be undertaken at the agency's initiative, unlike most shifts in judicial doctrine. If the need for flexibility is truly pressing, the APA gives the agency leeway to issue new rules outside of notice-and-comment procedure. This provides a suitable escape valve where the needs for flexibility are at their height." (footnotes omitted)).

310. See Nat'l Cable \& Telecomms. Ass'n v. Brand X Internet Servs., 545 U.S. 967, 982-83 (2005). 
interpretive rule interpreted the statute, regulations, or both. ${ }^{311}$

\section{Retention of Functionalism}

Establishing a new non-deferential standard of review would be motivated by reasons that are formal in nature, namely the separation of powers. Functionalism rather than formalism has, as we have seen, been at the center of the Court's explanation of Seminole Rock deference through its post-Chevron acceptance as Auer deference. ${ }^{312}$ The proposed standard of review does not abandon functionalism. Skidmore review retains functionalism, because it accounts for the agency's experience and expertise in its consideration of the agency's reasons for its interpretation. ${ }^{313}$ The agency's reasons for the interpretation, if they are persuasive because they are grounded in expertise and experience, may provide strong support for the interpretation and would accordingly be persuasive to a court, especially because the regulations have been determined to be ambiguous. In assessing the persuasiveness of the agency's position, a court would also be well-advised to consider its own functional limitations when the court resolves the question of administrative law. ${ }^{314}$ These functional limits may prompt a court to be more willing to accept the agency's position as its own. ${ }^{315}$ The court, of

311. To be sure, the standard of review that this article proposes does create a tension regarding the proper standard of review when an agency's interpretation is made in a formal adjudication. See supra notes 282-85 and accompanying text.

312. See supra notes 50-53, 107 and accompanying text. Cf. Stephenson \& Pogoriler, supra note 19, at 1490 ("[A] doctrinal limit on Seminole Rock's domain, then, would mean that Skidmore (or de novo review) would replace Seminole Rock as the governing standard of review in some regulatory policy areas. That result would be undesirable to the extent that it sacrifices the virtues associated with Seminole Rock-expertise, accountability, flexibility, and the like.").

313. Professor Strauss has emphasized that, when it applies the Skidmore regime, a court properly accounts for the agency's experience and expertise. See Strauss, "Deference" Is Too Confusing, supra note 76, at 1156 ("What is 'exclusively a judicial function' does not exclude agency views. Once a question of statutory interpretation has been put before a court, it is for the court to resolve the question of meaning. Among the matters indispensable for it to consider, however, are the meanings attributed to it by prior (administrative) interpreters, their stability, and the possibly superior body of information and more embracive responsibilities that underlay them. They may be entitled to great 'weight' on the judicial scales.").

314. See Strauss, "Deference" Is Too Confusing, supra note 76, at 1146 ("It is not only that agencies have the credibility of their circumstances, but also that they can contribute to an efficient, predictable, and nationally uniform understanding of the law that would be disrupted by the variable results to be expected from a geographically and politically diverse judiciary encountering the hardest (that is to say, the most likely to be litigated) issues with little experience with the overall scheme and its patterns.").

315. See Manning, supra note 6, at 688-89 ("Skidmore thus recognizes that an expert agency may be better positioned than a generalist court to understand and explain the specialized way in 
course, would hold the ultimate interpretive power.

The Court recently highlighted this distinction between a court giving weight to the views of another governmental body and a court being bound by that body's views. In Fisher $v$. University of Texas at Austin ${ }^{316}$ the Court considered the contention of the state university that it had complied with the requirements of strict scrutiny in its use of an affirmative action plan for the admission of a racially diverse student body. The Court held that, when a court applies the strict scrutiny test, the court may properly account for the university's experience, but the court itself must decide whether the test has been met:

Once the University has established that its goal of diversity is consistent with strict scrutiny, however, there must still be a further judicial determination that the admissions process meets strict scrutiny in its implementation. The University must prove that the means chosen by the University to attain diversity are narrowly tailored to that goal. On this point, the University receives no deference. Grutter made clear that it is for the courts, not for university administrators, to ensure that 'the means chosen to accomplish the government's asserted purpose must be specifically and narrowly framed to accomplish that purpose.' True, a court can take account of a university's experience and expertise in adopting or rejecting certain admissions processes. But, as the Court said in Grutter, it remains at all times the University's obligation to demonstrate, and the Judiciary's obligation to determine, that admissions processes 'ensure that each applicant is evaluated as an individual and not in a way that makes an applicant's race or ethnicity the defining feature of his or her application.'

When a court reviews an agency's interpretation of a regulation, the court must itself determine the proper interpretation, although the court ought to consider the agency's expert views when the court makes its decision. If a court were not persuaded by the agency's expertise and experience, the agency would retain the authority to amend its regulations to reflect the agency's experience-based interpretation of the statute by rule making. ${ }^{318}$ If the amended regulation were then challenged, the agency would receive Chevron deference for the new regulation. Chevron deference applies notwithstanding the agency's

\footnotetext{
which a regulatory community uses and understands its terms of art. It reminds courts that regulations often incorporate legal technicalities, and that a court should be open to an agency's expert testimony that particular terms were not used in the layperson's sense.").

316. 133 S. Ct. 2411 (2013).

317. Id. at 2419-20 (citations omitted).

318. See supra notes $308-10$ and accompanying text.
} 
change in position. ${ }^{319}$

\section{CONCLUSION}

For many years, courts have employed a very deferential standard of review when reviewing an agency's interpretation of its own regulations. Although this review standard has been widely accepted and applied, the Court has provided little theoretical support for the standard.

The Supreme Court has reshaped the law of judicial review of agency interpretations of statutes, most recently in Mead. Mead's effect has now begun to be felt when the Court reviews an agency's interpretation of its own regulations. This article has argued that the Court should take advantage of this time of uncertainty in the law to end the Auer/Seminole Rock line of cases.

The Court should establish a new standard of review that considers first whether the regulation is clear and applies any such clear regulatory requirement. If the regulation is ambiguous, the court would apply a standard of review that is analogous to Skidmore review by which the court itself has the power to interpret the ambiguous regulation. Under this regime, an agency would not bind a court by its interpretation, but would have an opportunity to convince the court to adopt the agency's interpretation, informed as it may be by the agency's experience and expertise. The Court should make it clear that, when this new standard of review is employed, the court, rather than the agency, wields the interpretive power. The court should properly be the decider in this context. That role is consistent with the Constitution, the APA, and the structure of administrative law.

319. See Nat'l Cable \& Telecomms. Ass'n v. Brand X Internet Servs., 545 U.S. 967, 981-82 (2005). The agency's change in position would be considered in deciding whether the agency was arbitrary or capricious in promulgating the amended regulation. See Healy, supra note 1, at 50-51. 